\title{
Nitrogen deposition: how important is it for global terrestrial carbon uptake?
}

\author{
G. Bala ${ }^{1}$, N. Devaraju ${ }^{1}$, R. K. Chaturvedi ${ }^{2}$, K. Caldeira ${ }^{3}$, and R. Nemani ${ }^{4}$ \\ ${ }^{1}$ Divecha Center for Climate Change and Center for Atmospheric and Oceanic Sciences, Indian Institute of Science, \\ Bangalore 560012, India \\ ${ }^{2}$ Center for Sustainable Technologies, Indian Institute of Science, Bangalore 560012, India \\ ${ }^{3}$ Department of Global Ecology, Carnegie Institution, 260 Panama Street, Stanford, CA 94305, USA \\ ${ }^{4}$ NASA Ames Research Center, Moffett Field, CA 94035, USA
}

Correspondence to: G. Bala (gbala@caos.iisc.ernet.in)

Received: 17 May 2013 - Published in Biogeosciences Discuss.: 4 July 2013

Revised: 4 October 2013 - Accepted: 11 October 2013 - Published: 11 November 2013

\begin{abstract}
Global carbon budget studies indicate that the terrestrial ecosystems have remained a large sink for carbon despite widespread deforestation activities. $\mathrm{CO}_{2}$ fertilization, $\mathrm{N}$ deposition and re-growth of mid-latitude forests are believed to be key drivers for land carbon uptake. In this study, we assess the importance of $\mathrm{N}$ deposition by performing idealized near-equilibrium simulations using the Community Land Model 4.0 (CLM4). In our equilibrium simulations, only $12-17 \%$ of the deposited nitrogen is assimilated into the ecosystem and the corresponding carbon uptake can be inferred from a $\mathrm{C}: \mathrm{N}$ ratio of $20: 1$. We calculate the sensitivity of the terrestrial biosphere for $\mathrm{CO}_{2}$ fertilization, climate warming and $\mathrm{N}$ deposition as changes in total ecosystem carbon for unit changes in global mean atmospheric $\mathrm{CO}_{2}$ concentration, global mean temperature and Tera grams of nitrogen deposition per year, respectively. Based on these sensitivities, it is estimated that about $242 \mathrm{PgC}$ could have been taken up by land due to the $\mathrm{CO}_{2}$ fertilization effect and an additional $175 \mathrm{PgC}$ taken up as a result of the increased $\mathrm{N}$ deposition since the pre-industrial period. Because of climate warming, the terrestrial ecosystem could have lost about $152 \mathrm{PgC}$ during the same period. Therefore, since preindustrial times terrestrial carbon losses due to warming may have been more or less compensated by effects of increased $\mathrm{N}$ deposition, whereas the effect of $\mathrm{CO}_{2}$ fertilization is approximately indicative of the current increase in terrestrial carbon stock. Our simulations also suggest that the sensitivity of carbon storage to increased $\mathrm{N}$ deposition decreases beyond current levels, indicating that climate warming effects
\end{abstract}

on carbon storage may overwhelm $\mathrm{N}$ deposition effects in the future.

\section{Introduction}

Though nitrogen is the most abundant element in the atmosphere, most organisms, including plants and animals, cannot use it in its most common form $\left(\mathrm{N}_{2}\right)$. It can only be used in its reactive forms of $\mathrm{NO}_{\mathrm{y}}$ and $\mathrm{NH}_{\mathrm{x}}$, which when deposited on the surface through various processes, is generally referred to as "nitrogen deposition". Since pre-historic times, nitrogen has been converted to bioavailable forms through "lightening", bacteria, algae, legumes and plants with associative $\mathrm{N}_{2}$ fixers. The rate of nitrogen fixation (and thus deposition) has significantly increased due to systematic cultivation of rice and leguminous plants. The rate is estimated to be $\sim 10.8 \mathrm{TgN} \mathrm{yr}^{-1}$ (Tera grams of nitrogen per year) around 1765 (Galloway et al., 2004; Jain et al., 2009) and around 17.4 $\mathrm{TgN} \mathrm{yr}^{-1}$ by 1865 (Galloway et al., 2004).

In the industrial era, nitrogen deposition has increased many times due to nitrogenous emissions from fossil fuel combustion, and due to industrial production of various reactive nitrogen compounds from the Haber-Bosch process. As a result, $\mathrm{N}$ deposition increased to about $60 \mathrm{TgN} \mathrm{yr}^{-1}$ in the 1990s (Galloway et al., 2004; Jain et al., 2009) and is projected to increase to about $125 \mathrm{TgN} \mathrm{yr}^{-1}$ by 2050 (Galloway et al., 2004). Estimates of $\mathrm{N}$ deposition based on $\mathrm{NO}_{\mathrm{y}}$ 
emissions alone are between 25 and $40 \mathrm{TgN} \mathrm{yr}^{-1}$ for the year 2000 and $60-100 \mathrm{TgN} \mathrm{yr}^{-1}$ by 2100 (Lamarque et al., 2005).

Global carbon budget studies suggest that the global terrestrial ecosystem has remained a large sink of carbon in recent decades, despite a widespread deforestation-related flux of carbon to the atmosphere (Friedlingstein et al., 2010; Le Quere et al., 2009; Pan et al., 2011; Schimel, 1995). Regrowth of mid-latitude forests, $\mathrm{CO}_{2}$ fertilization and nitrogen deposition are believed to be key drivers for land carbon uptake (Canadell et al., 2007; Friedlingstein et al., 2010; IPCC, 2007). There have been many observational studies on $\mathrm{CO}_{2}$ fertilization which yield a range of results (Korner, 2006). For example, free-air $\mathrm{CO}_{2}$ enrichment experiments in forest stands (Norby et al., 2005) indicate a $23 \%$ median increase in net primary production (NPP) in response to a $\mathrm{CO}_{2}$ concentration increase from 376 to $550 \mathrm{ppm}$ (parts per million), but some studies (Newingham et al., 2013) show no significant effect. It appears that the effect strongly depends on the availability of nutrients and soil water, the plant species and state (young vs. mature) of the ecosystems (Korner, 2006). Warming, in contrast, is known to diminish the land carbon sink by enhancing respiration (Cox et al., 2000; Cramer et al., 2001; Friedlingstein et al., 2001; Govindasamy et al., 2005; Joos et al., 1991; Lloyd and Taylor, 1994; Matthews et al., 2005; Thompson et al., 2004; Zeng et al., 2004). Global mean temperature is estimated to have increased by about $0.74{ }^{\circ} \mathrm{C}$ in the period 1906 to 2005 (IPCC, 2007).

A number of observational studies from different geographical areas have shown that $\mathrm{N}$ deposition increases carbon stocks in different plant species (see Table S1 for a brief list of studies and their results). While the amount of additional carbon stock increase depends on the plant functional type, location, type of ecosystem ( $\mathrm{N}$ limited or not) and other environmental conditions, the upper bound can be estimated from the $\mathrm{C}: \mathrm{N}$ ratio of the ecosystems: an estimate of the upper bound for the present-day would be $1-2 \mathrm{PgC}$ per year for a $\mathrm{C}: \mathrm{N}$ ratio of $20-40: 1$, and a $50 \mathrm{TgN} \mathrm{yr}^{-1}$ increase in $\mathrm{N}$ deposition relative to pre-industrial period. Beyond certain $\mathrm{N}$ deposition levels, additional $\mathrm{N}$ deposition has reduced impact on biomass yield and productivity (Lemus et al., 2008; Rasmussen, 1998). While modeling studies show that $\mathrm{N}$ deposition increases NPP and carbon stocks (Jain et al., 2009; Magnani et al., 2007; Thornton et al., 2009; Yang et al., 2009), the importance of $\mathrm{N}$ deposition relative to $\mathrm{CO}_{2}$ fertilization effects and temperature increases has not been adequately explored on a global scale. A recent coupled modeling study shows $\mathrm{N}$ deposition and elevated $\mathrm{CO}_{2}$ could have a synergistic effect, which could explain $47 \%$ of terrestrial carbon uptake in the 1990s (Churkina et al., 2009). Estimates of global terrestrial carbon uptake due to current $\mathrm{N}$ deposition ranges: from $0.15-0.35 \mathrm{PgC} \mathrm{yr}^{-1}(10-20 \%$ of terrestrial uptake) (de Vries, 2009; de Vries et al., 2008; Zaehle and Dalmonech, 2011) to $1.0-2.0 \mathrm{PgC} \mathrm{yr}^{-1}$ (100\% of terrestrial uptake) (de Vries, 2009; de Vries et al., 2008; Holland et al., 1997; Magnani et al., 2007; Zaehle and Dalmonech,
2011) or $0.31 \mathrm{PgC} \mathrm{yr}^{-1}$ in tree carbon storage (Thomas et al., 2010). However, there are indications that $\mathrm{N}$-induced increase in land carbon uptake is unlikely to keep pace with future $\mathrm{CO}_{2}$ increases (Reay et al., 2008).

Terrestrial carbon accumulation could be constrained by the availability of nitrogen (Hungate et al., 2003; Nadelhoffer et al., 1999) and because of this constraint it has been found (Bonan and Levis, 2010; Jain et al., 2009; Thornton et al., 2009; Yang et al., 2009) that nitrogen cycle dynamics attenuates the magnitude of global terrestrial carbon sinks and sources driven by $\mathrm{CO}_{2}$ fertilization and changes in climate. However, it is not clear how the sensitivity of terrestrial carbon uptake to $\mathrm{N}$ deposition will change under climate warming and changing atmospheric $\mathrm{CO}_{2}$ concentrations. In this study, we address the following three questions:

1. How much carbon could be sequestered into terrestrial ecosystem per $\mathrm{TgN} \mathrm{yr}^{-1}$ increase in $\mathrm{N}$ deposition?

2. How does the sensitivity to $\mathrm{N}$ deposition respond to the changing temperature and $\mathrm{CO}_{2}$ concentration?

3. What is the importance of $\mathrm{N}$ deposition relative to $\mathrm{CO}_{2}$ fertilization and global warming in determining total ecosystem carbon storage? Total ecosystem carbon (TEC) is the sum of all terrestrial carbon pools in vegetation, soil and litter.

To address these issues, we use a global land model coupled to carbon and nitrogen cycles. Our simulations are highly idealized since our main goal here is to get an order of magnitude estimate for the sensitivity of terrestrial ecosystem to $\mathrm{N}$ deposition, climate warming and $\mathrm{CO}_{2}$ fertilization. Further, we design near-equilibrium simulations as opposed to transient simulations since there could be substantial lags in terrestrial ecosystem response (Jones et al., 2009) and equilibrium simulations allow us to capture long-term consequences. However, it should be cautioned that the sensitivity parameters estimated from equilibrium simulations have much larger magnitudes when compared in transient simulations as shown in one of our recent studies (Bala et al., 2012). Though our simulations are highly idealized, the results may have important implications for the terrestrial carbon dynamics for the historical and future periods.

\section{Model description}

To investigate the relative influence of $\mathrm{N}$ deposition, $\mathrm{CO}_{2}$ fertilization and climate warming on ecosystem carbon productivity, we use the Community Land Model CLM4 (Lawrence et al., 2011). CLM4 merges the biophysical framework of the CLM 3.5 (Oleson et al., 2008, 2010; Stockli et al., 2008) with the terrestrial biogeochemistry model Biome BGC (version 4.1.2) (Thornton and Rosenbloom, 2005; Thornton et al., 2002). CLM4 includes revised hydrology and snow models, 
organic soils, and a $50 \mathrm{~m}$-deep ground column when compared to CLM3.5. Additionally in CLM4 the distribution of plant functional types (PFTs) is modified to reduce a high grass bias in forested regions. It includes carbon-nitrogen biogeochemistry with prognostic carbon and nitrogen in vegetation, litter, and soil organic matter (Thornton and Zimmermann, 2007; Thornton et al., 2009). A prognostic fire model simulates wildfires (Kloster et al., 2010). In CLM4, nitrogen input to the ecosystem is via biological fixation and $\mathrm{N}$ deposition. Within the ecosystem, nitrogen is released from organic matter (gross mineralization) in forms that can then be taken up by plants (plant uptake or assimilation) and the remaining is immobilized (immobilization). $\mathrm{N}$ losses from the ecosystem are through fire loss, denitrification and leaching.

The offline simulations of CLM4 need atmospheric forcing (or climate) data which is also provided along with the source code distribution of CLM4. The forcing data is a $57 \mathrm{yr}$ (1948-2004) observationally constrained atmospheric data set at three-hourly intervals for surface air temperature, precipitation, surface pressure, boundary layer wind and surface solar radiation at a horizontal resolution of $1.9^{\circ}$ latitude and 2.5 longitude (Qian et al., 2006). Inputs to the model such as the initial conditions, the surface parameters and the PFT physiological constants were all set from the input data set associated with the distribution of CLM4 source code. The 15 PFTs that are prescribed in the model correspond to present-day vegetation cover, while land cover and land use change is not considered. A prescribed constant level of atmospheric $\mathrm{CO}_{2}$ concentration forcing is used for each simulation.

\section{Experiments}

CLM4 simulations in this study are started from a well spun-up state (restart files supplied along with source code by NCAR) corresponding to pre-industrial levels of atmospheric $\mathrm{CO}_{2}$ concentration (285 ppm) and $\mathrm{N}$ deposition $\left(20.3 \mathrm{TgN} \mathrm{yr}^{-1}\right)$. When we continue this case for $1000 \mathrm{yr}$ (the control experiment $1 \mathrm{~N}$ as discussed below), the drift in global total ecosystem carbon is only $0.015 \mathrm{PgC}$ per year, suggesting that the control simulation is in near-equilibrium state. From this well spun-up pre-industrial state provided by NCAR, we initiate twelve $1000 \mathrm{yr}$ simulations with the same climate forcing but varying $\mathrm{N}$ deposition, $\mathrm{CO}_{2}$ concentrations and climate warming over the globe to isolate the effects of these factors on global ecosystem productivity and carbon storage. The twelve experiments are grouped into 3 sets; (1-4): $1 \mathrm{~N}$ (Control), $2 \mathrm{~N}, 4 \mathrm{~N}$ and $8 \mathrm{~N}$ where atmospheric $\mathrm{CO}_{2}$ concentration is fixed at the pre-industrial levels (285 ppm; year 1850) and $\mathrm{N}$ deposition is $1 \times, 2 \times, 4 \times$ and $8 \times$ the pre-industrial levels, respectively; $(5-8): 1 \mathrm{~N} 2 \times \mathrm{CO}_{2}$, $2 \mathrm{~N} 2 \times \mathrm{CO}_{2}, 4 \mathrm{~N} 2 \times \mathrm{CO}_{2}$ and $8 \mathrm{~N} 2 \times \mathrm{CO}_{2}$ are the same as $(1-$ 4) but the $\mathrm{CO}_{2}$ level is doubled; and (9-12): $1 \mathrm{~N} 2 \mathrm{~K}, 2 \mathrm{~N} 2 \mathrm{~K}$,
$4 \mathrm{~N} 2 \mathrm{~K}$ and $8 \mathrm{~N} 2 \mathrm{~K}$ are the same as (1-4) but a uniform increase of $2 \mathrm{~K}$ in atmospheric temperature forcing is imposed.

In the above simulations, changes in $\mathrm{N}$ deposition, $\mathrm{CO}_{2}$ and climate warming are imposed as step-function changes at the start of the simulations. It should be noted that we refer to $1 \mathrm{~N}$ as pre-industrial control though we use vegetation types corresponding to present-day and use a $57 \mathrm{yr}$ forcing data set that corresponds to the period1948-2005. During the last $100 \mathrm{yr}$ period, net ecosystem exchange (NEE) has had a magnitude between 0.01 and $0.1 \mathrm{PgC} \mathrm{yr}^{-1}$ in all the simulations and hence the simulations are considered to be in near-steady state. The $57 \mathrm{yr}$ atmospheric forcing data set is repeatedly used in all twelve $1000 \mathrm{yr}$ experiments. The influence of the $57 \mathrm{yr}$ cycle or short-term trend in our simulations is removed by either applying a $57 \mathrm{yr}$ running average or by showing differences between the experiments (subtraction of one experiment from another removes the $57 \mathrm{yr}$ trends cycles) in our analysis.

The prescription of nitrogen deposition in our simulations is designed so as to capture the pre-industrial, current and projected future nitrogen deposition levels on the global land system: $\mathrm{N}$ deposition in $1 \mathrm{~N}$ (pre-industrial period) and $2 \mathrm{~N}$ are prescribed at $20.3 \mathrm{TgN} \mathrm{yr}^{-1}$ (Bonan and Levis, 2010) and $40.6 \mathrm{TgN} \mathrm{yr}^{-1}$, respectively, over land, whereas the present-day $\mathrm{N}$ deposition is $65.2 \mathrm{TgN} \mathrm{yr}^{-1}$ in CLM4 data set. The $\mathrm{N}$ deposition used in CLM4 (Fig. 1) were generated by the three-dimensional chemistry transport MOZART-2 (Model for Ozone and Related Tracers, version 2; Horowitz et al., 2003). These $\mathrm{N}$ deposition levels are close to the values reported in literature, i.e. $17.4 \mathrm{TgN} \mathrm{yr}^{-1}$ in 1860 and $62 \mathrm{TgN} \mathrm{yr}^{-1}$ in the year 2000 (Galloway et al., 2004; Jain et al., 2009). The prescribed $\mathrm{N}$ deposition over land in the experiment $8 \mathrm{~N}$ is $162.4 \mathrm{TgN} \mathrm{yr}^{-1}$ while the projected $\mathrm{N}$ deposition in 2050 is $135 \mathrm{TgN} \mathrm{yr}^{-1}$ (Galloway et al., 2004).

While the first set of experiments (1-4) is designed to estimate the response of the model to $\mathrm{N}$ deposition, the second set of experiments (5-8) is designed to estimate the sensitivity of the model to $\mathrm{CO}_{2}$ fertilization and the interaction between $\mathrm{CO}_{2}$ fertilization with $\mathrm{N}$ deposition. The third set of experiments (9-12) is designed to calculate the sensitivity to climate warning and its interaction with $\mathrm{N}$ deposition.

\section{Results and discussion}

The spatial pattern of $\mathrm{N}$ deposition used in our experiments based on pre-industrial $\mathrm{N}$ deposition is similar to present-day deposition with a correlation coefficient of 0.87 for deposition over land (Fig. 1). South and Southeast Asia, Europe, eastern North America and Central Africa have larger $\mathrm{N}$ deposition. The pattern of deposition is primarily determined by sources of reactive nitrogen inputs to the atmosphere, atmospheric transport and wet and dry deposition processes in the atmosphere (Horowitz et al., 2003). 


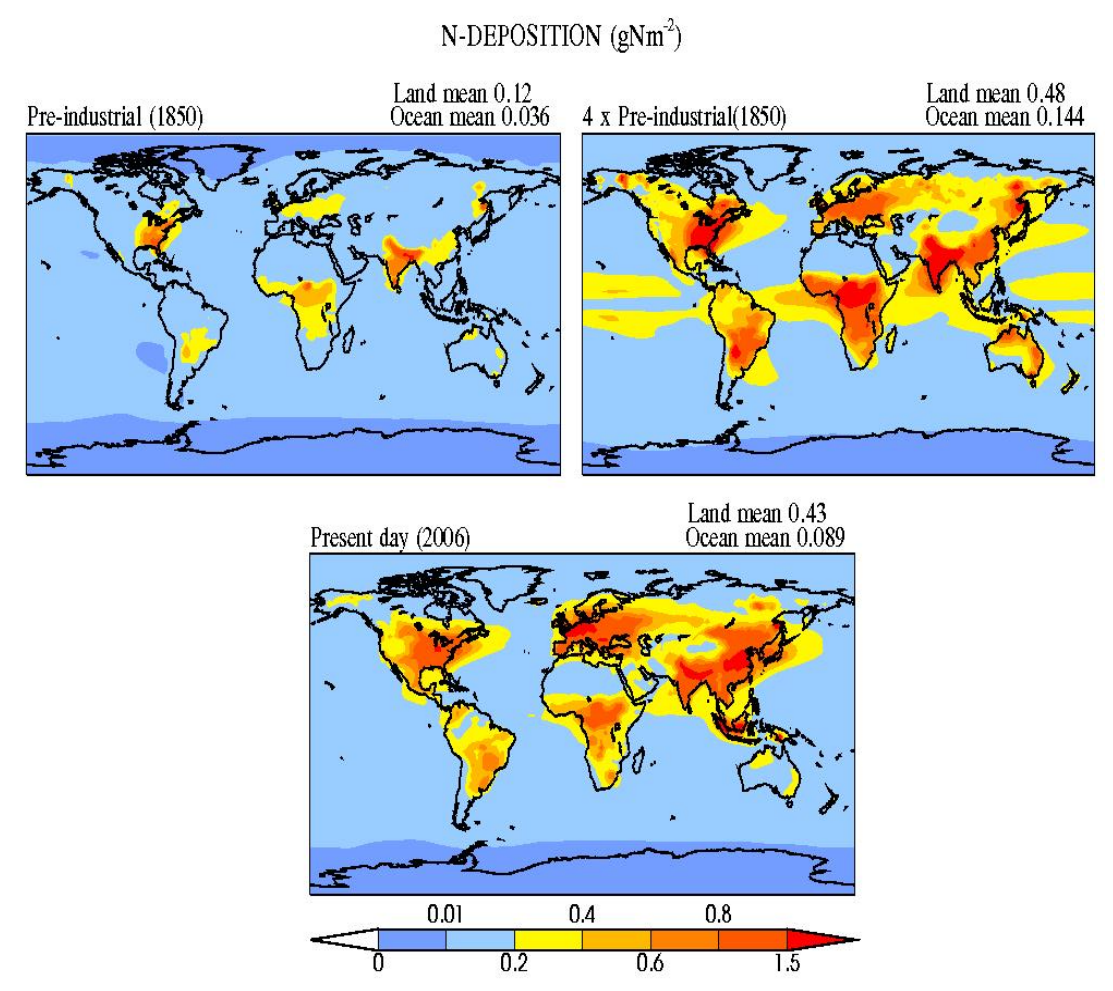

Fig. 1. Spatial distribution of $\mathrm{N}$ deposition in the pre-industrial period (1850; top left panel), four times the pre-industrial $\mathrm{N}$ deposition case (4N; top right panel) and present-day (2006; bottom panel) in the input data sets of CLM4. The global mean pre-industrial N deposition over land is $0.12 \mathrm{gN} \mathrm{m}^{-2}$ (a total land deposition of $20.3 \mathrm{TgN} \mathrm{yr}^{-1}$ ). The deposition in the experiment $4 \mathrm{~N}\left(80.6 \mathrm{TgN} \mathrm{yr}^{-1}\right)$ is approximately close to the present-day deposition of $0.43 \mathrm{gN} \mathrm{m}^{-2}\left(\sim 73.1 \mathrm{TgN} \mathrm{yr}^{-1}\right)$. We infer from this figure that the spatial pattern of $\mathrm{N}$ deposition used in our experiments is similar to present-day deposition.

The changes in key terrestrial carbon cycle variables (Net Primary Productivity (NPP), vegetation carbon, soil carbon and total ecosystem carbon) for elevated $\mathrm{N}$ deposition are shown in Fig. 2, which shows that the simulations have reached near-equilibrium conditions after $900 \mathrm{yr}$ and hence we use the last $100 \mathrm{yr}$ in our analysis. During the last $100 \mathrm{yr}$ period, net ecosystem exchange (NEE) has had a magnitude between 0.01 and $0.1 \mathrm{PgC} \mathrm{yr}^{-1}$ in all the simulations. Figure 2 suggests that as the N deposition increases, NPP, vegetation carbon, soil carbon and TEC also increase. It demonstrates that the model adequately represents the $\mathrm{N}$ limitation in the terrestrial ecosystems (Vitousek and Howarth, 1991) as the addition of $\mathrm{N}$ deposition results in an increase of simulated NPP. It also suggests that at lower N deposition levels the terrestrial ecosystem is more sensitive to the addition of nitrogen and is less sensitive at higher $\mathrm{N}$ deposition levels. Further, we find that climate warming leads to a decrease in TEC and the decrease is larger when $\mathrm{N}$ deposition levels are larger. The causes for the dependence of sensitivity on $\mathrm{N}$ deposition levels are discussed in the following paragraphs.

Figure 3 and Table 1 show that the simulated TEC averaged over the near-equilibrium period $(900-1000 \mathrm{yr})$ increases substantially as the $\mathrm{N}$ deposition rate is increased.
The increases are $69 \mathrm{PgC}(3.6 \%), 183.5 \mathrm{PgC}(9.4 \%)$, and $352 \mathrm{PgC}(18.1 \%)$ for two times, four times and eight times the $\mathrm{N}$ deposition, respectively. TEC increases per $\mathrm{TgN} \mathrm{yr}^{-1}$ are $3.41,3.01$, and $2.48 \mathrm{PgC} /\left(\mathrm{TgN} \mathrm{yr}^{-1}\right)$ for these three cases, respectively. That is, TEC increase per unit $\mathrm{N}$ deposition becomes smaller for large $\mathrm{N}$ deposition, and eventually the system would reach steady state and thus the land biosphere would eventually stop being a carbon sink (Rasmussen, 1998). The sensitivity for $\mathrm{N}$ deposition decreases at higher $\mathrm{N}$ deposition levels in the real world because of other factors such as water or availability of other nutrients, especially phosphorous, which would eventually limit ecosystem productivity. These limitations are represented in the model by parameterizing biological nitrogen fixation (BNF; an input of $\mathrm{N}$ to terrestrial ecosystem) as a function of NPP (Oleson et al., 2010):

$\mathrm{BNF}=1.8(1-\exp [-0.003 \mathrm{NPP}])$

This formulation captures the observed broad-scale dependency of BNF on ecosystem productivity (Oleson et al., 2010).

An exponential fit with 2 time constants shows that major changes in TEC occur on decadal and centennial timescales 


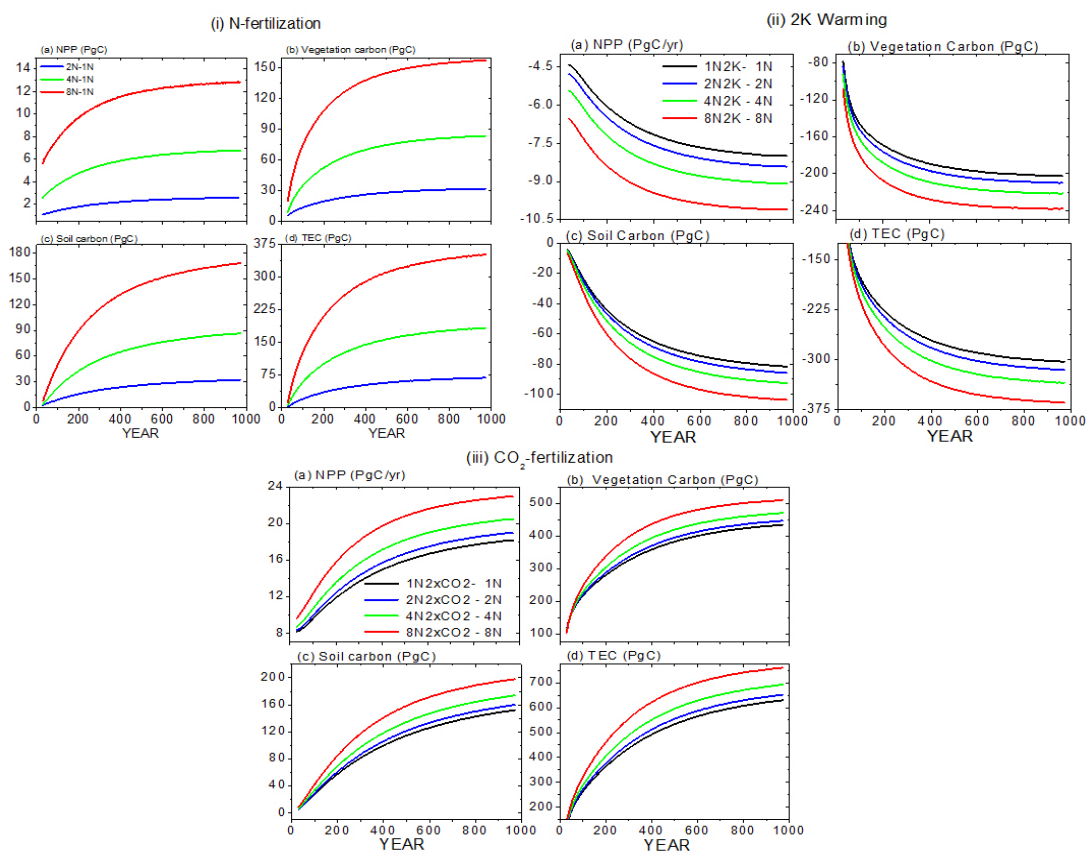

Fig. 2. CLM4 simulated global and annual mean changes in NPP, vegetation carbon, soil carbon and total ecosystem carbon for (i) N deposition, (ii) climate warming and (iii) $\mathrm{CO}_{2}$ fertilization at various levels of $\mathrm{N}$ deposition. A 57 yr running average is applied to original annual mean data.

Table 1. Global mean changes in key ecosystem variables in the last $100 \mathrm{yr}$ of $1000 \mathrm{yr}$ simulations. Values in parentheses are $\%$ changes.

\begin{tabular}{|c|c|c|c|c|c|c|c|c|c|c|c|c|}
\hline \multirow[t]{2}{*}{$\begin{array}{l}\text { Key Terrestrial } \\
\text { Variables }\end{array}$} & \multirow[t]{2}{*}{$1 \mathrm{~N}$} & \multicolumn{3}{|c|}{$\begin{array}{l}\text { Set } 1 \text { Experiments: } \\
\text { Increasing } \mathrm{N} \\
\text { deposition alone }\end{array}$} & \multicolumn{4}{|c|}{$\begin{array}{l}\text { Set } 2 \text { Experiments: } \\
\text { Increasing } \mathrm{N} \text { deposition } \\
\text { with } 2 \mathrm{~K} \text { warming }\end{array}$} & \multicolumn{4}{|c|}{$\begin{array}{l}\text { Set } 3 \text { Experiments: Increasing } \mathrm{N} \\
\text { deposition with doubled } \mathrm{CO}_{2} \\
\text { concentration }\end{array}$} \\
\hline & & $2 \mathrm{~N}-1 \mathrm{~N}$ & $4 \mathrm{~N}-1 \mathrm{~N}$ & $8 \mathrm{~N}-1 \mathrm{~N}$ & $1 \mathrm{~N} 2 \mathrm{~K}-1 \mathrm{~N}$ & $2 \mathrm{~N} 2 \mathrm{~K}-2 \mathrm{~N}$ & $4 \mathrm{~N} 2 \mathrm{~K}-4 \mathrm{~N}$ & $8 \mathrm{~N} 2 \mathrm{~K}-8 \mathrm{~N}$ & $1 \mathrm{~N} 2 \times \mathrm{CO} 2-1 \mathrm{~N}$ & $2 \mathrm{~N} 2 \times \mathrm{CO} 2-2 \mathrm{~N}$ & $4 \mathrm{~N} 2 \times \mathrm{CO} 2-4 \mathrm{~N}$ & $8 \mathrm{~N} 2 \times \mathrm{CO} 2-8 \mathrm{~N}$ \\
\hline $\operatorname{GPP}\left(\mathrm{PgC} \mathrm{yr}^{-1}\right)$ & 184.4 & $6.2(3.4)$ & $16.4(8.9)$ & $30.8(16.7)$ & $-17.4(-9.4)$ & $-18.4(-9.7)$ & $-20.0(-10.0)$ & $-22.2(-10.3)$ & $53.8(29.2)$ & $56.0(29.4)$ & $60.0(29.9)$ & $66.8(31.0)$ \\
\hline $\mathrm{NPP}\left(\mathrm{PgC} \mathrm{yr}^{-1}\right)$ & 63.8 & $2.6(4.0)$ & $6.8(10.6)$ & $12.8(20.1)$ & $-8.0(-12.6)$ & $-8.4(-12.7)$ & $-9.1(-12.9)$ & $-10.1(-13.2)$ & $18.0(28.2)$ & $18.8(28.3)$ & $20.3(28.7)$ & $22.8(29.7)$ \\
\hline Vegetation carbon $(\mathrm{PgC})$ & 1066.8 & $28.0(3.0)$ & $45.6(4.7)$ & $65.4(6.45)$ & $-179.0(-19.0)$ & $-185.7(-19.2)$ & $-195.8(-19.3)$ & $-210.5(-19.5)$ & $432.8(40.6)$ & $445.3(40.5)$ & $468.9(40.8)$ & $508.3(41.5)$ \\
\hline Vegetation nitrogen $(\mathrm{PgN})$ & 4.9 & $0.2(3.5)$ & $0.5(9.1)$ & $0.9(17.3)$ & $-0.7(-14.8)$ & $-0.8(-14.9)$ & $-0.8(-15.0)$ & $-0.9(-15.3)$ & $1.6(31.9)$ & $1.6(32.0)$ & $1.7(32.4)$ & $1.9(33.3)$ \\
\hline Soil carbon $(\mathrm{PgC})$ & 743.8 & $32.2(4.3)$ & $86.5(11.6)$ & $168.1(22.6)$ & $-81.5(-11.0)$ & $-85.6(-11.0)$ & $-92.5(-11.1)$ & $-103.6(-11.4)$ & $151.1(20.3)$ & $158.8(20.5)$ & $172.7(20.8)$ & $196.9(21.6)$ \\
\hline Soil nitrogen $(\mathrm{PgN})$ & 74.2 & $3.2(4.3)$ & $8.6(11.6)$ & $16.8(22.6)$ & $-8.1(-11.0)$ & $-8.5(-11.0)$ & $-9.2(-11.1)$ & $-10.3(-11.4)$ & $15.1(20.3)$ & $15.8(20.5)$ & $17.2(20.8)$ & $19.7(21.6)$ \\
\hline Total ecosystem carbon $(\mathrm{PgC})$ & 1946.1 & $69.0(3.6)$ & $183.5(9.4)$ & $351.9(18.1)$ & $-303.4(-15.6)$ & $-315.8(-15.7)$ & $-335.5(-15.8)$ & $-365.1(-15.9)$ & $627.7(32.3)$ & $649.5(32.2)$ & $689.9(32.4)$ & $758.4(33.0)$ \\
\hline Total ecosystem nitrogen $(\mathrm{PgN})$ & 79.6 & $3.4(4.3)$ & $9.1(11.5)$ & $17.7(22.2)$ & $-8.9(-11.2)$ & $-9.4(-11.3)$ & $-10.1(-11.4)$ & $-11.3(-11.6)$ & $16.8(21.1)$ & $17.6(21.2)$ & $19.1(21.5)$ & $21.7(22.3)$ \\
\hline
\end{tabular}

for step function changes in $\mathrm{N}$ deposition, temperature and $\mathrm{CO}_{2}$ (Table S2). Therefore, on centennial timescales, the order of magnitude TEC increase for $\mathrm{N}$ deposition can be inferred from accumulation of total ecosystem nitrogen (TEN; Table 1) due to $\mathrm{N}$ deposition. Carbon and nitrogen flow in parallel between vegetation, litter and soil organic matter, respecting the stoichiometry of the various organic matter pools. In CLM4, the $\mathrm{C}: \mathrm{N}$ ratio for leaf, wood, root and soil pools are $30: 1,130: 1,55: 1$ and $10: 1$, respectively. When carbon stocks are weighted with the fraction of carbon and nitrogen in these pools as in the $1 \mathrm{~N}$ case, we find an average $\mathrm{C}: \mathrm{N}$ ratio of about $20: 1$, which is consistent with the approximate ratio of TEC to TEN in Table 1. Therefore, when $\mathrm{N}$ deposition is increased by $20.3 \mathrm{TgN} \mathrm{yr}^{-1}(2 \mathrm{~N}-1 \mathrm{~N})$, we find an increase in TEN of $3.4 \mathrm{PgN}$ and an associated TEC increase of $69 \mathrm{PgC}$.

Our model-based estimate is conservative when compared to observations in European sites that find a carbon sequestration range of $5-75 \mathrm{KgC}(\mathrm{KgN})^{-1}$ for forests and heart- lands and a most common range of $20-40 \mathrm{KgC}(\mathrm{KgN})^{-1}$ (de Vries et al., 2009) or US sites which find an above-ground biomass increment of $61 \mathrm{~kg}$ of carbon per $\mathrm{kg}$ of nitrogen deposited (Thomas et al., 2010). Our model calculations presented here are for the global mean case, that is the average from all 15 PFTs, but the measurement results cited are only for the forest PFTs. Therefore, it is not surprising that the $\mathrm{N}$ deposition effect for the forests is higher than modeled global mean case, because forests have large $\mathrm{C}$ storage capacity. Defining an overall $\mathrm{N}$ accumulation fraction as the ratio of ecosystem $\mathrm{N}$ accumulation to $\mathrm{N}$ deposition for the entire period $(1000 \mathrm{yr})$, we get an $\mathrm{N}$ accumulation fraction in the range of $12-17 \%(12 \%$ for $8 \mathrm{~N}-1 \mathrm{~N}$ and $17 \%$ for $2 \mathrm{~N}-$ $1 \mathrm{~N}$ ) and the remaining $\mathrm{N}$ is lost to atmosphere through denitrification, fire loss and leaching (Fig. 5). Therefore, for our equilibrium simulations only $12-17 \%$ of the deposited nitrogen is assimilated into the ecosystem and the corresponding carbon uptake can be inferred from a $\mathrm{C}: \mathrm{N}$ ratio of $20: 1$. 


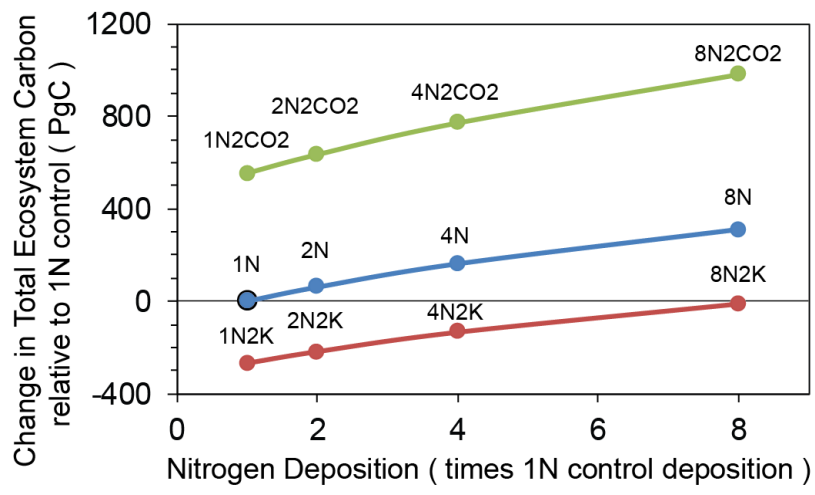

Fig. 3. Total Ecosystem Carbon (TEC) changes relative to the control simulation $(1 \mathrm{~N})$ in the three sets of simulations. Blue line shows effect of increased $\mathrm{N}$ deposition. Green line shows effect of both doubled atmospheric $\mathrm{CO}_{2}$ content and added $\mathrm{N}$ deposition. Brown line shows effect of both $2 \mathrm{~K}$ warming and added $\mathrm{N}$ deposition. The effect of an eight-fold increase in $\mathrm{N}$ deposition is approximately the same magnitude but opposite in sign to that of a $2 \mathrm{~K}$ warming.

Figure 3 also shows that under the warming scenario, the simulated TEC averaged over the years 900-1000 declines for all $\mathrm{N}$ deposition levels except $8 \mathrm{~N} 2 \mathrm{~K}$. This suggests that the magnitude of the effect of $2 \mathrm{~K}$ warming is the same as $8 \mathrm{~N}$. Thus, in this model, the TEC decline due to the $2 \mathrm{~K}$ warming overwhelms the TEC increase associated with $\mathrm{N}$ deposition until $\mathrm{N}$ deposition reaches 8 times pre-industrial levels. Warming is expected to cause increased decomposition, increased nitrogen mineralization, and hence increased primary production - thereby offsetting some of the increased carbon release from soils that could otherwise provide a positive feedback to global warming. The model does simulate greater soil mineral nitrogen per unit soil carbon for $2 \mathrm{~K}$ warming (Fig. S1). However, we find that the total amount of mineral nitrogen declines in the warming cases (Fig. S1) because the amount of soil carbon is smaller due to the decline in ecosystem productivity (Fig. 2) in the $2 \mathrm{~K}$ warming cases. This is consistent with declines in TEC in these cases (Fig. 3).

The TEC decreases for a $2 \mathrm{~K}$ warming by 303.4 (15.6\%), $315.8(15.7 \%), 335.5(15.8 \%)$ and $365.1(15.9 \%) \mathrm{PgC}$, respectively, at pre-industrial level $\mathrm{N}$ deposition $(1 \mathrm{~N} 2 \mathrm{~K}-1 \mathrm{~N}), 2$ times $(2 \mathrm{~N} 2 \mathrm{~K}-2 \mathrm{~N}), 4$ times $(4 \mathrm{~N} 2 \mathrm{~K}-4 \mathrm{~N})$ and 8 times $(8 \mathrm{~N} 2 \mathrm{~K}-$ $8 \mathrm{~N}$ ) the pre-industrial $\mathrm{N}$ deposition levels. While the absolute magnitudes of these changes show an increase with the background $\mathrm{N}$ deposition levels, the similar percentage changes suggest that the sensitivity of TEC to warming remains almost a constant for the levels of $\mathrm{N}$ deposition considered in this study. This indicates a "pool size" effect: at higher $\mathrm{N}$ deposition levels, the carbon stocks are higher and hence the change per unit warming is larger though the percentage change is constant.
The $\mathrm{CO}_{2}$ fertilization leads to an increase in TEC at all levels of $\mathrm{N}$ deposition (Fig. 3). The simulated TEC averaged over the years 900-1000 increases for a doubling of $\mathrm{CO}_{2}$ by 627.7 (32.3\%), 649.5 (32.2\%), 689.9 (32.4\%) and 758.4 (33\%) $\mathrm{PgC}$ respectively, at pre-industrial level $\mathrm{N}$ deposition $\left(1 \mathrm{~N} 2 \times \mathrm{CO}_{2}-1 \mathrm{~N}\right), 2$ times $\left(2 \mathrm{~N} 2 \times \mathrm{CO}_{2}-2 \mathrm{~N}\right)$, 4 times $\left(4 \mathrm{~N} 2 \times \mathrm{CO}_{2}-4 \mathrm{~N}\right)$ and 8 times $\left(8 \mathrm{~N} 2 \times \mathrm{CO}_{2}-8 \mathrm{~N}\right)$ the pre-industrial $\mathrm{N}$ deposition levels. The percentage changes suggest that the sensitivity of TEC to $\mathrm{CO}_{2}$ fertilization also remains almost a constant for the levels of $\mathrm{N}$ deposition considered in this study. However, the absolute magnitudes show an increase with the background $\mathrm{N}$ deposition levels as was the case with warming, indicating the "pool size" effect identified above.

Spatial pattern of changes in TEC under different $\mathrm{N}$ deposition levels and under warming and $\mathrm{CO}_{2}$ fertilization levels for the last $100 \mathrm{yr}$ of simulations are shown in Fig. 4. Overall, $\mathrm{N}$ deposition leads to enhanced TEC (Fig. 4) as increased N deposition leads to increased BNF (Fig. 5). Most of the increase in TEC is located in regions where trees are the dominant plant functional types (Lawrence et al., 2011). We also find that climate warming leads to a decline in TEC except in northern high latitudes (Fig. 4), where warming results in increased growing season and increased TEC. $\mathrm{CO}_{2}$ fertilization causes an increase in TEC everywhere with centers of maxima seen in the Amazon, central Africa and Southeast Asia (Fig. 4). Climate warming and $\mathrm{CO}_{2}$ fertilization lead to decrease and increase in total ecosystem nitrogen, respectively, respectively, in total ecosystem nitrogen which is primarily driven by changes in denitrification, BNF and fire loss nitrogen (Fig. 6).

The feedbacks of terrestrial biosphere to increasing $\mathrm{CO}_{2}$ concentration and warming have been well quantified (Bala et al., 2012; Boer and Arora, 2009; Friedlingstein et al., 2003, 2006; Zickfeld et al., 2011) using two parameters that determine the land carbon uptake: the carbon storage sensitivity over land to $\mathrm{CO}_{2}\left(\beta_{\mathrm{L}}\right.$; beta) and to temperature change $\left(\gamma_{\mathrm{L}}\right.$; gamma). In this study we introduce a new sensitivity parameter, i.e. carbon storage sensitivity over land to $\mathrm{N}$ deposition $\left(\delta_{\mathrm{L}}\right.$; delta) to quantify the response for $\mathrm{N}$ deposition. $\beta_{\mathrm{L}}$ is defined (Bala et al., 2012; Friedlingstein et al., 2003, 2006) as the change in TEC associated with unit change in atmospheric $\mathrm{CO}_{2}\left(C_{\mathrm{a}}\right), \gamma_{\mathrm{L}}$ as the change in TEC associated with unit change in temperature, and $\delta_{\mathrm{L}}$ as the change in TEC associated with unit change in atmospheric $\mathrm{N}$ deposition:

$$
\begin{aligned}
& \beta_{\mathrm{L}}=\frac{\Delta \mathrm{TEC}}{\Delta C_{\mathrm{a}}} \\
& \gamma_{\mathrm{L}}=\frac{\Delta \mathrm{TEC}}{\Delta T}
\end{aligned}
$$

$$
\delta_{\mathrm{L}}=\frac{\Delta \mathrm{TEC}}{\Delta N}
$$




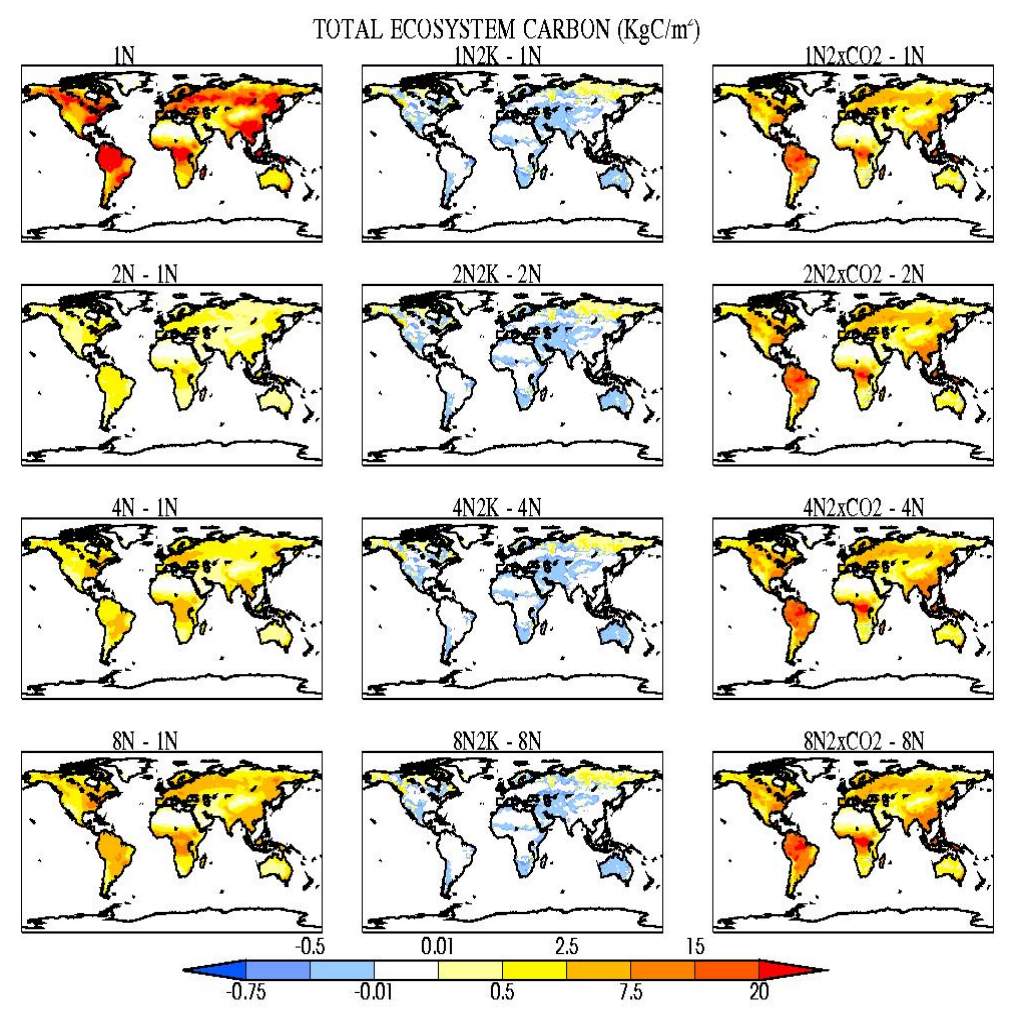

Fig. 4. Total ecosystem carbon (TEC) changes in the three sets of simulations. Left panels show TEC changes for N deposition and middle and right panels show TEC changes for climate warming and $\mathrm{CO}_{2}$ fertilization under different background $\mathrm{N}$ deposition, respectively.
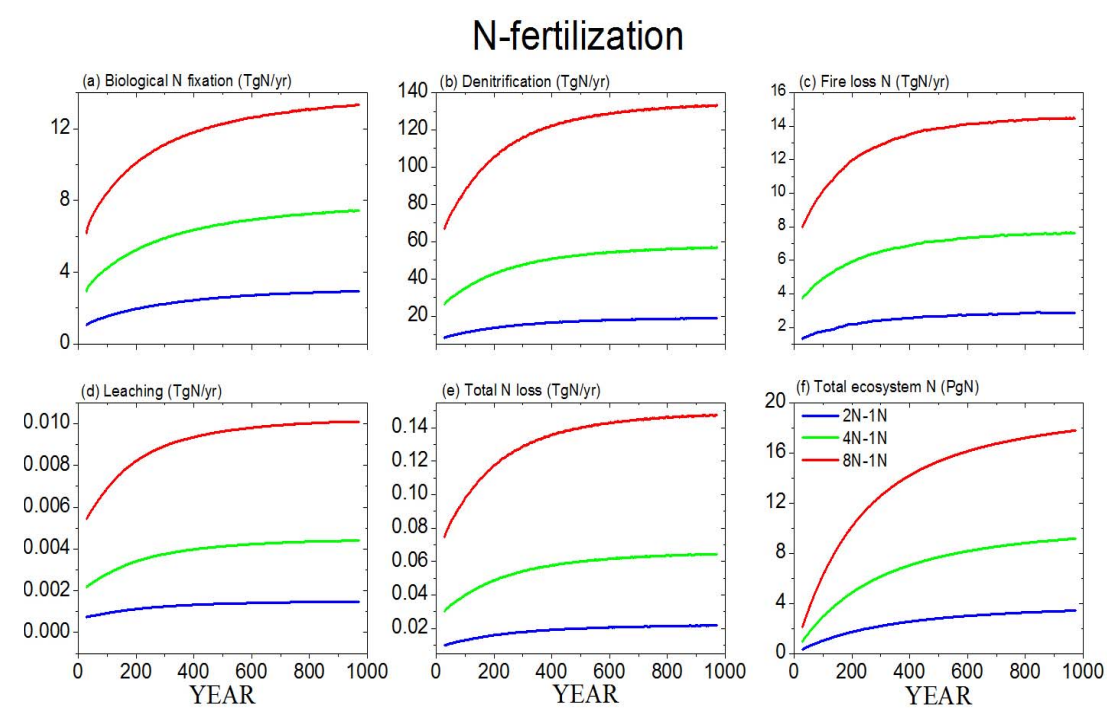

Fig. 5. Changes in $\mathrm{N}$ budget for the terrestrial ecosystem in $2 \mathrm{~N}$ (blue line), $4 \mathrm{~N}$ (green line) and $8 \mathrm{~N}$ (red line) simulations relative to $1 \mathrm{~N}$ : changes in annual mean (a) biological $\mathrm{N}$ fixation (BNF), (b) denitrification, (c) fire loss $\mathrm{N}$, (d) leaching, and (e) the total $\mathrm{N}$ loss from ecosystem (sum of denitrification, fire loss $\mathrm{N}$ and leaching). Total ecosystem $\mathrm{N}$ (f) is the cumulative sum of BNF and $\mathrm{N}$ deposition (constant in time for all simulations) minus cumulative sum of total $\mathrm{N}$ loss from ecosystem. A $57 \mathrm{yr}$ running average is applied to original annual mean data. 

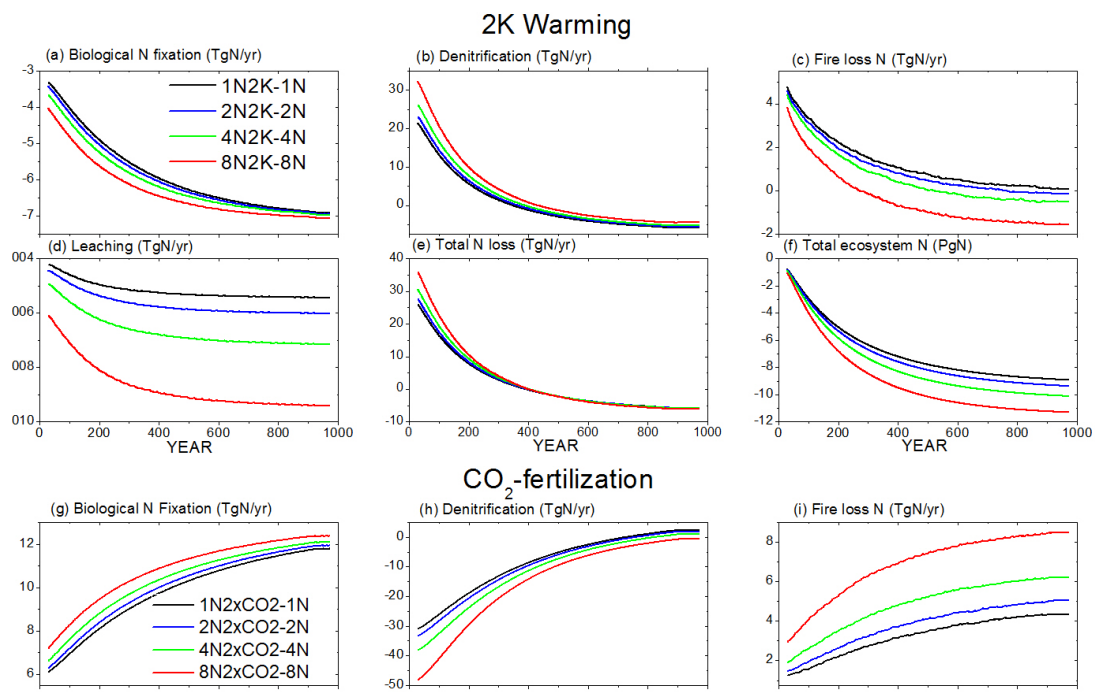

$\mathrm{CO}_{2}$-fertilization
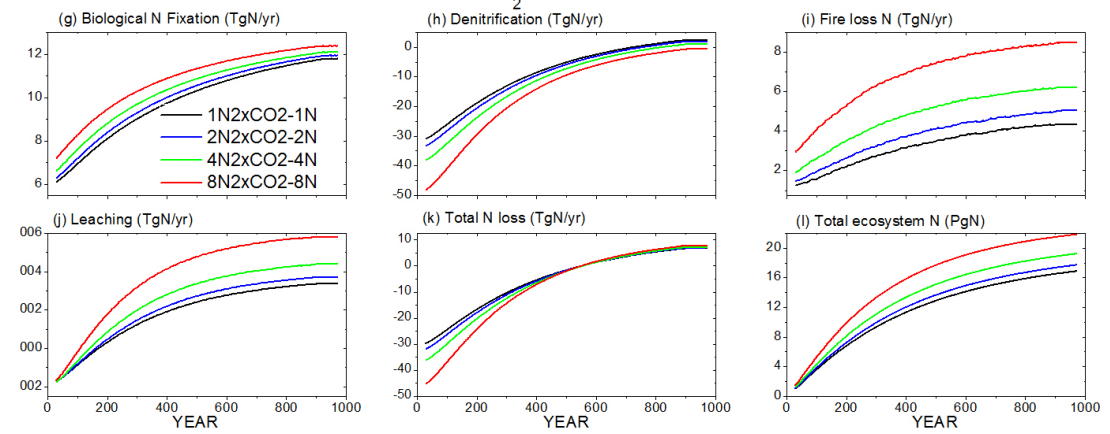

Fig. 6. Changes in $\mathrm{N}$ variables for the terrestrial ecosystem in the $1000 \mathrm{yr}$ simulations $1 \mathrm{~N}$ (black line), $2 \mathrm{~N}$ (blue line), $4 \mathrm{~N}$ (green line) and $8 \mathrm{~N}$ (red line) in presence of $2 \mathrm{~K}$ warming (a-f) and $\mathrm{CO}_{2}$ fertilization (g-l): the global- and annual-mean changes of (a, g) biological $\mathrm{N}$ fixation (BNF), (b, h) denitrification, (c, i) fire loss $\mathrm{N},(\mathbf{d}, \mathbf{j})$ leaching, $(\mathbf{e}, \mathbf{k})$ total $\mathrm{N}$ loss from ecosystem (sum of denitrification, fire loss $\mathrm{N}$ and leaching) and (f, l) total ecosystem $\mathrm{N}$ (TEN). The order of magnitude of $\mathrm{N}$ fluxes indicates that denitrification flux is the dominant process controlling $\mathrm{N}$ stock changes. We find that the TEN losses in (e) are higher in the presence of $2 \mathrm{~K}$ warming at higher $\mathrm{N}$ deposition levels due to larger decline in biological $\mathrm{N}$ fixation (a) and increase in denitrification (b). In the case of $\mathrm{CO}_{2}$ fertilization, TEN gains are larger at higher $\mathrm{N}$ deposition levels because of a larger increase in $\mathrm{BNF}$ and decline in denitrification.

where $C_{\mathrm{a}}, T$ and $N$ refer to atmospheric $\mathrm{CO}_{2}$ concentrations, global-mean surface temperature and atmospheric $\mathrm{N}$ deposition to soil mineral nitrogen, respectively.

Table 2 shows the values of $\beta_{\mathrm{L}}, \gamma_{\mathrm{L}}$ and $\delta_{\mathrm{L}}$ and the time evolution of these parameters are shown in Fig. 7. We find that $\mathrm{CO}_{2}$ fertilization $\left(\beta_{L}\right)$ and $\mathrm{N}$ deposition $\left(\delta_{\mathrm{L}}\right)$ lead to increases in TEC. TEC increases $\sim 2.21 \mathrm{PgC} \mathrm{ppm}^{-1}$ (computed from $1 \mathrm{~N} 2 \times \mathrm{CO}_{2}$ and $1 \mathrm{~N}$ ) in response to increased atmospheric $\mathrm{CO}_{2}$ concentration, and by $\sim 3.41 \mathrm{PgC} /\left(\mathrm{TgN} \mathrm{yr}^{-1}\right.$ ) (computed from $2 \mathrm{~N}$ and $1 \mathrm{~N}$ ) in response to increased $\mathrm{N}$ deposition. However, warming causes TEC to decrease by $\sim 152 \mathrm{PgC} \mathrm{K}^{-1}$ (computed from $1 \mathrm{~N} 2 \mathrm{~K}$ and $1 \mathrm{~N}$ ). Table 2 also suggests that with the increasing terrestrial $\mathrm{N}$ deposition, the magnitude of TEC sensitivity to $\mathrm{CO}_{2}$ fertilization increases as does the negative TEC sensitivity to warming due to the "pool size" effect discussed earlier. Further, we find that TEC sensitivity to $\mathrm{N}$ deposition decreases with increasing $\mathrm{N}$ deposition levels and it increases (decreases) in the presence of $\mathrm{CO}_{2}$ fertilization (climate warming). The equilibrium values of $\beta_{\mathrm{L}}$ and $\gamma_{\mathrm{L}}$ in our simulations also are larger (Bala et al., 2012) when compared with previous transient CCSM simulations and stand-alone land model simulations (Bonan and Levis, 2010; Thornton et al., 2009). For a doubling of $\mathrm{CO}_{2}$,
Table 2. Terrestrial ecosystem carbon (TEC) sensitivity to $\mathrm{CO}_{2}$ fertilization $\left(\beta_{\mathrm{L}}\right)$ and its changes under increasing $\mathrm{N}$ deposition, TEC sensitivity to warming $\left(\gamma_{\mathrm{L}}\right)$ and its changes under increasing $\mathrm{N}$ deposition and TEC sensitivity to nitrogen deposition $\left(\delta_{\mathrm{L}}\right)$ and its changes under increasing $\mathrm{CO}_{2}$ concentration and warming. The pairs of experiments used to calculate the sensitivities are shown in Fig. 7.

\begin{tabular}{lll|lll}
\hline & $\beta_{\mathrm{L}}\left(\mathrm{PgC} \mathrm{ppm}^{-1}\right)$ & $\gamma_{\mathrm{L}}\left(\mathrm{PgC} \mathrm{K}^{-1}\right)$ & \multicolumn{3}{|c}{$\delta_{\mathrm{L}}\left(\mathrm{PgC} /\left(\mathrm{TgN} \mathrm{yr}^{-1}\right)\right)$} \\
\hline $1 \mathrm{~N}$ & 2.21 & -152 & $\mathrm{~N}$ deposition & With $2 \times \mathrm{CO}_{2}$ & With $2 \mathrm{~K}$ \\
$2 \mathrm{~N}$ & 2.30 & -158 & 3.41 & 4.48 & 2.79 \\
$4 \mathrm{~N}$ & 2.43 & -167.7 & 3.01 & 4.03 & 2.48 \\
$8 \mathrm{~N}$ & 2.67 & -182 & 2.47 & 3.39 & 2.04 \\
\hline
\end{tabular}

the TEC increases by $32.3 \%$ after $900 \mathrm{yr}$ of stabilization, which is close to the $28 \%$ increase found by a recent study (Bala et al., 2012) for a doubling $\mathrm{CO}_{2}$ in a coupled climate model.

Our value of $\delta_{\mathrm{L}}$ is consistent with a previous study (Nadelhoffer et al., 1999) which suggests a carbon sequestration of $0.25 \mathrm{PgC} \mathrm{yr}^{-1}$ from increased $\mathrm{N}$ deposition: our value of $3.41 \mathrm{PgC} /\left(\mathrm{TgN} \mathrm{yr}^{-1}\right)$ over $1000 \mathrm{yr}$ translates to $0.17 \mathrm{PgC} \mathrm{yr}^{-1}$ for an increase in $\mathrm{N}$ deposition of about $50 \mathrm{TgN} \mathrm{yr}^{-1}$ since the pre-industrial period. 


\section{Sensitivity of TEC}
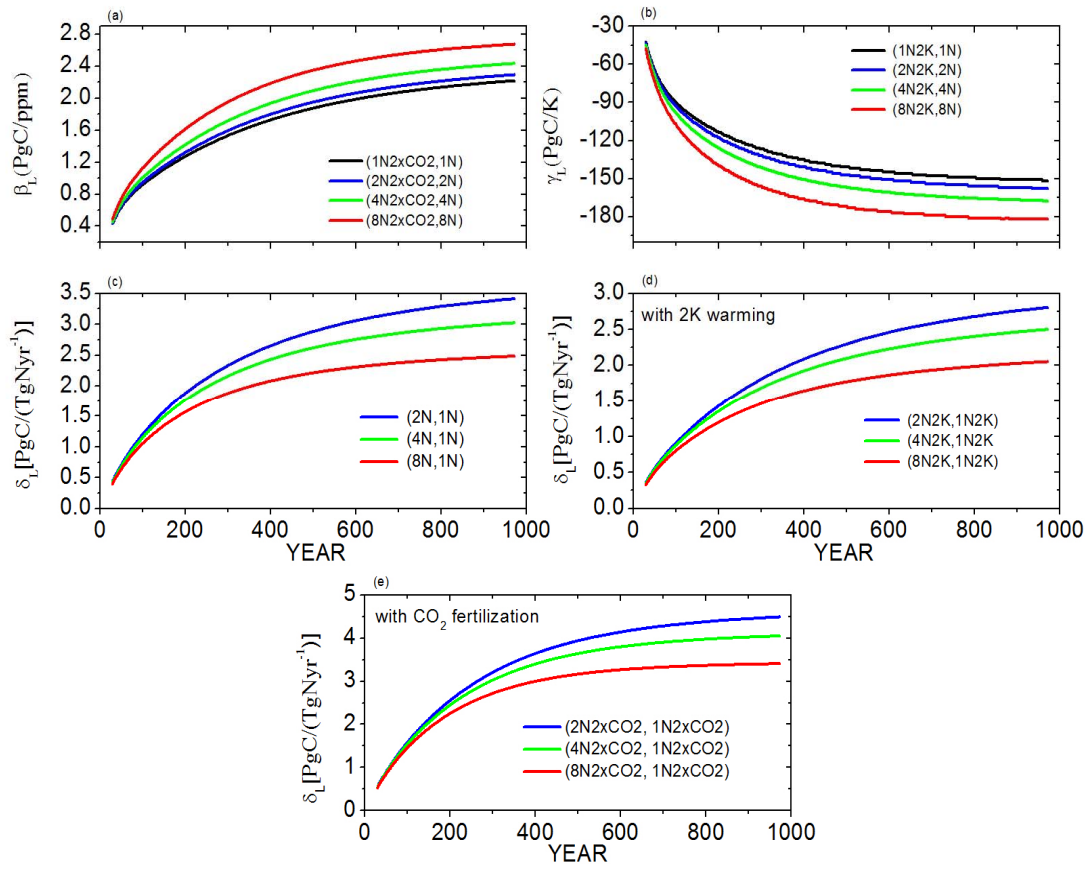

Fig. 7. Evolution of terrestrial ecosystem carbon (TEC) storage sensitivity to $\mathrm{CO}_{2}$, climate warming and increased $\mathrm{N}$ deposition in our $1000 \mathrm{yr}$ simulations. TEC sensitivity to (a) atmospheric $\mathrm{CO}_{2}\left(\beta_{\mathrm{L}}\right)$ at different levels of $\mathrm{N}$ deposition, (b) temperature $\left(\gamma_{\mathrm{L}}\right)$ at different levels of $\mathrm{N}$ deposition, (c) $\mathrm{N}$ deposition $\left(\delta_{\mathrm{L}}\right)$, (d) $\mathrm{N}$ deposition $\left(\delta_{\mathrm{L}}\right)$ in presence of $2 \mathrm{~K}$ warming and (e) $\mathrm{N}$ deposition $\left(\delta_{\mathrm{L}}\right)$ in the presence of doubled $\mathrm{CO}_{2}$. A $57 \mathrm{yr}$ running average is applied to original annual mean TEC data. The pairs of experiments indicated in the legend are the experiments that are used to calculate the respective sensitivities (Eqs. 1-3).

Figure 8 shows that $\beta_{\mathrm{L}}$ is positive at all land points and $\beta_{\mathrm{L}}$ shows a slight increase as $\mathrm{N}$ deposition levels increase (Table 2). $\gamma_{\mathrm{L}}$ decreases in most regions (Fig. 8) because climate warming results in reduced NPP and the consequent declines in vegetation and soil carbon. However, in the northern high latitudes warming leads to higher ecosystem productivity and hence positive $\gamma_{\mathrm{L}}$ values. At higher levels of $\mathrm{N}$ deposition concentrations, unit increase in temperature results in larger ecosystem carbon losses (Table 2). At lower levels of $\mathrm{N}$ deposition concentration, an increase in $\mathrm{N}$ deposition results in larger ecosystem carbon increases and tropical and temperature regions show relatively large increases in TEC as $\mathrm{N}$ deposition increases from $1 \mathrm{~N}$ to $2 \mathrm{~N}$ (Fig. 8). However at higher levels of $\mathrm{N}$ deposition, increases are moderate. Also TEC sensitivity to $\mathrm{N}$ deposition decreases for present-day deposition when compared to pre-industrial $\mathrm{N}$ deposition levels (Fig. S2). This shows that the magnitude of TEC sensitivity to $\mathrm{N}$ deposition is likely to decrease beyond current $\mathrm{N}$ deposition levels.

We perform an additional simulation (1NPREC2K) to investigate effects of hydrological cycle changes, because in our climate warming simulations we have imposed only temperature changes, but not the associated changes in other important variables such as precipitation, water vapor and clouds. In 1NPREC2K, we imposed a uniform increase in precipitation of $6 \%$ and specific humidity increase of $13 \%$ in association with the $2 \mathrm{~K}$ warming as global mean precipitation and specific humidity are constrained to increase by $\sim 3 \%$ and $6.5 \%$ per unit warming, respectively (Allen and Ingram, 2002; Held and Soden, 2006). A comparison of spatial pattern of changes in TEC in 1 NPREC $2 \mathrm{~K}$ and $1 \mathrm{~N} 2 \mathrm{~K}$ indicates that the experiment $1 \mathrm{~N} 2 \mathrm{~K}$ without the climate-changerelated precipitation and water vapor changes is able to simulate the TEC changes associated with a $2 \mathrm{~K}$ global mean warming very well (Fig. S3) as regional differences in TEC between $1 \mathrm{NPREC} 2 \mathrm{~K}$ and $1 \mathrm{~N} 2 \mathrm{~K}$ are at most only $\sim 10-15 \%$. Further, increased $\mathrm{N}$ deposition could potentially affect the hydrological cycle by increasing the leaf area index and canopy transpiration. However, we find that the simulated effect of $\mathrm{N}$ deposition on land hydrological cycle is much smaller when compared to effects from $\mathrm{CO}_{2}$ fertilization and climate warming (Fig. S4).

Finally, we assess if there is any nonlinearity (or two-way interaction) in our simulations (Table S3). We find that the combined effect for warming and $\mathrm{N}$ deposition is approximately close to the sum of individual effects at smaller $\mathrm{N}$ deposition levels indicating the near-absence of two-way interactions. However, larger deviations from linearity appear 


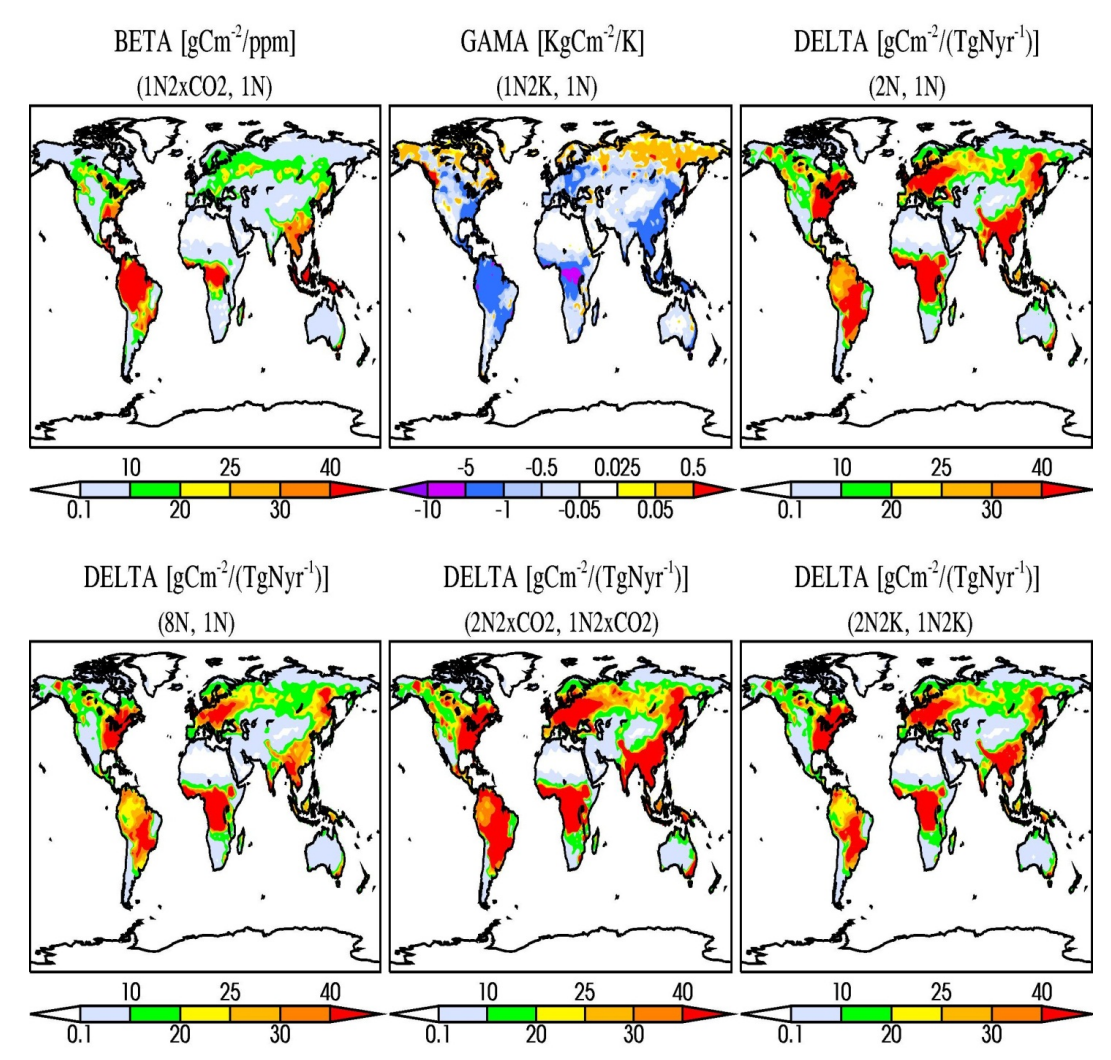

Fig. 8. Spatial pattern of total ecosystem carbon (TEC) sensitivity for $\mathrm{CO}_{2}$ change $\left(\beta_{\mathrm{L}}\right)$, climate change $\left(\gamma_{\mathrm{L}}\right)$ and $\mathrm{N}$ deposition $\left(\delta_{\mathrm{L}}\right.$; top panels). The experiments used in the calculation of sensitivity are shown in the parenthesis. The bottom panels illustrate the changes in delta for larger changes in $\mathrm{N}$ deposition (general decline), and in the presence of $\mathrm{CO}_{2}$ fertilization (increase) and climate change (decline).

at larger $\mathrm{N}$ deposition. For instance, at eight times the preindustrial $\mathrm{N}$ deposition levels the difference between combined effect and sum of effects is about $62 \mathrm{PgC}$, which is about $10 \%$ of the sum of the magnitudes of the individual effects. The interaction between climate change and $\mathrm{N}$ deposition imply a loss of TEC and the sign of net TEC change is altered by the interaction (Table S3). Similar near-linearity at small $\mathrm{N}$ deposition and significant nonlinearity at higher $\mathrm{N}$ deposition can be seen for the combination of $\mathrm{CO}_{2}$ fertilization and $\mathrm{N}$ deposition effects (Table S3). In this case, the interaction implies a gain of TEC for ecosystems and again the nonlinearity is about $10 \%$. The negative sign of the two-way interaction for climate change and positive sign for $\mathrm{CO}_{2}$ fertilization are merely a reflection of the fact that the TEC sensitivity to $\mathrm{N}$ deposition $\left(\delta_{\mathrm{L}}\right)$ is larger under $\mathrm{CO}_{2}$ fertilization and smaller under climate change (Table 2). These nonlinear interactions would suggest that the role of $\mathrm{N}$ deposition will vary in the future depending on climate change and the $\mathrm{CO}_{2}$ levels. For instance, the interaction term may be more important under a higher emission scenario such as RCP8.5 (Representative Concentration Pathway 8.5) than under RCP2.6.

\section{Conclusions}

What are the key drivers of the terrestrial carbon uptake in the recent decades? While the role of carbon fertilization and climate warming is well studied, the role of nitrogen deposition remains underexplored. $\mathrm{N}$ deposition has increased from $10.8 \mathrm{TgN}$ in 1765 to $62.2 \mathrm{TgN}$ in 2000 (Galloway et al., 2004; Jain et al., 2009). During the same period, the atmospheric $\mathrm{CO}_{2}$ has increased by about $110 \mathrm{ppm}$ and the global mean temperature has increased by about 1 $\mathrm{K}$ (IPCC, 2007). Our analysis of the TEC sensitivity to $\mathrm{CO}_{2}$ fertilization $\left(\beta_{\mathrm{L}}\right)$ and $\mathrm{N}$ deposition $\left(\delta_{\mathrm{L}}\right)$ suggests that about $242 \mathrm{PgC}\left(110 \mathrm{ppm} \times 2.2 \mathrm{PgC} \mathrm{ppm}^{-1}\right)$ could have been taken up by land due to the $\mathrm{CO}_{2}$ fertilization effect and an additional $175 \mathrm{PgC}\left(51.4 \mathrm{TgN} \mathrm{yr}^{-1} \times 3.4 \mathrm{PgC} /\left(\mathrm{TgN} \mathrm{yr}^{-1}\right)\right)$ taken up as a result of the increased $\mathrm{N}$ deposition since the preindustrial period. Because of climate warming $\left(\gamma_{\mathrm{L}}\right)$, terrestrial ecosystems could have lost about $152 \mathrm{PgC}$ during the same period, assuming a warming of about $1 \mathrm{~K}$. The zonal mean percentage changes in TEC due to these three factors show similar orders of magnitude (Fig. 9, right panels). We caution that our estimates provide only an order of magnitude of the three effects considered in this study since our simulations are idealized near-equilibrium simulations. We 

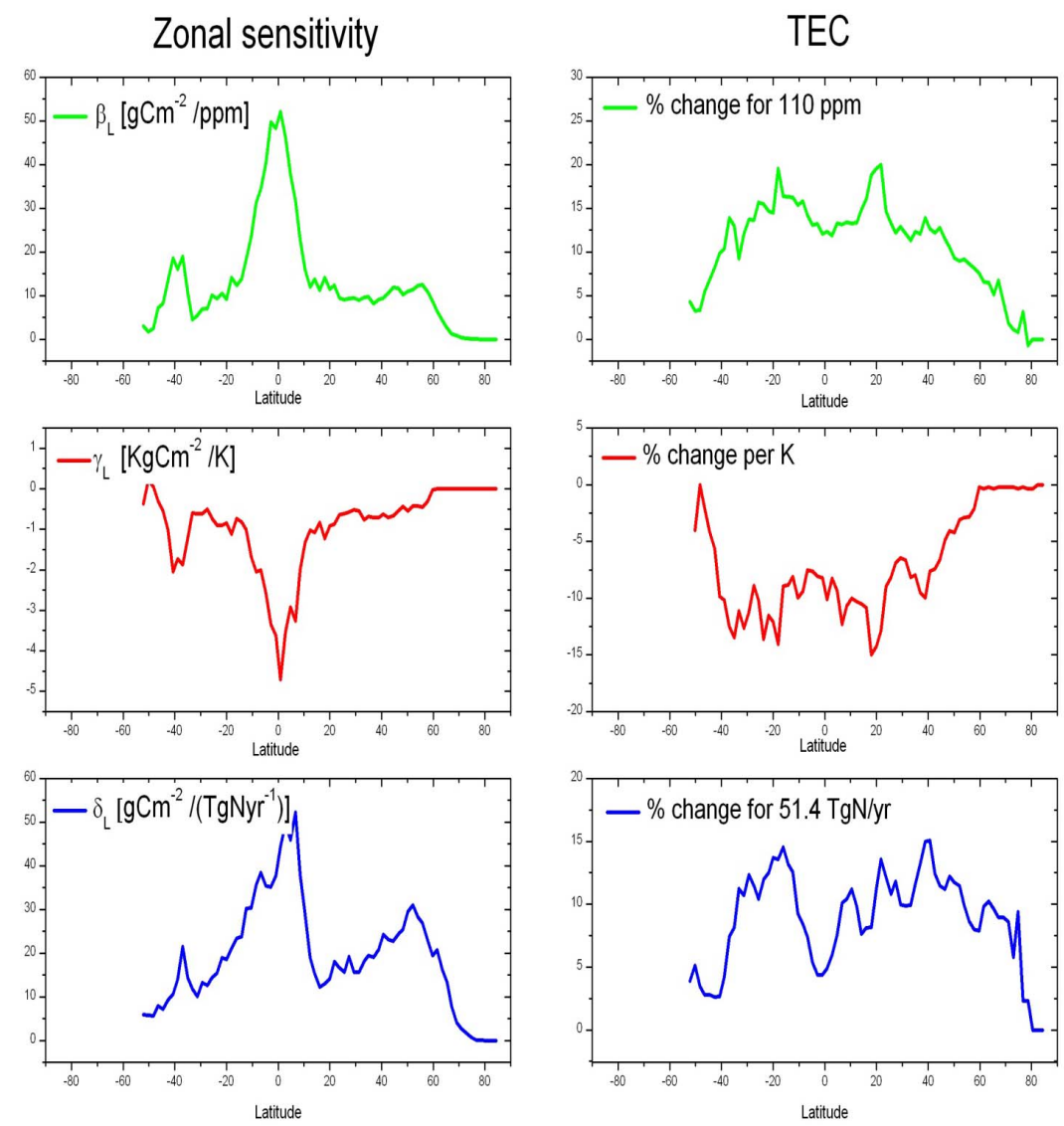

Fig. 9. Zonal mean pattern total ecosystem carbon (TEC) sensitivity for $\mathrm{CO}_{2}$ change $\left(\beta_{\mathrm{L}}\right)$, climate change $\left(\gamma_{\mathrm{L}}\right)$ and $\mathrm{N}$ deposition $\left(\delta_{\mathrm{L}}\right.$; left panels). The right panels show the percentage changes in TEC during the historical period due to $\mathrm{CO}_{2}$ change (110 ppm), climate warming $(\sim 1 \mathrm{~K})$ and $\mathrm{N}$ deposition $\left(51.4 \mathrm{TgN} \mathrm{yr}^{-1}\right)$.

are justified in using near-equilibrium sensitivity values for the transient historical period since major TEC changes occur on decadal and centennial timescales (Table S2).

These estimates indicate that TEC losses due to increased warming have likely been more than compensated by the additional $\mathrm{N}$ deposition since the pre-industrial period (Fig. 9). The land biosphere has been a sink for carbon because $\mathrm{N}$ deposition and warming impacts more or less cancel each other out, while a $\mathrm{CO}_{2}$ fertilization effect is feeding the current increase in ecosystem productivity. While the contribution of $\mathrm{CO}_{2}$ fertilization and warming to TEC are well known, our study suggests $\mathrm{N}$ deposition to be an equally important factor controlling the terrestrial carbon cycle. There have been indeed suggestions that terrestrial carbon loss due to deforestation and agriculture may have been more or less balanced by nitrogen-stimulated carbon uptake (Schindler and Bayley, 1993). The $\mathrm{N}$ deposition is projected to increase by about 8 times by the 2050s relative to pre-industrial levels (Galloway et al., 2004). Our analysis suggests that as $\mathrm{N}$ deposition increases the sensitivity of TEC to $\mathrm{N}$ deposition decreases (Fig. 7) due to two factors. First, for a constant $\mathrm{N}$ de- position rate, the annual increase in TEC decreases with time (see the exponential fit for TEC changes in Table S2). Second, for a specified amount of increase in $\mathrm{N}$ deposition the increase in TEC decreases with the amount of pre-existing $\mathrm{N}$ deposition. Both of these factors would lead to a decrease in the magnitude of TEC increase over time. Therefore, it is likely that increasing $\mathrm{N}$ deposition may not be able to compensate the loss in TEC caused by warming in the future.

Our findings should be viewed in the light of the limitations and uncertainties involved in this study. One of the key limitations is that we have used an offline version of CLM4 and hence the feedbacks with other components of the climate system (e.g. atmosphere and ocean) are missing in our simulations. However, our results should not differ substantively from those obtained with more comprehensive models, and use of a simpler model permits isolation of effects of different causal factors (i.e., $\mathrm{CO}_{2}$ level, temperature, and amount of $\mathrm{N}$ deposition). For instance, our present analysis suggests that TEC could increase by $628 \mathrm{PgC}(32.3 \%)$ for a doubling of $\mathrm{CO}_{2}$, which is in close agreement with a recent study (Bala et al., 2012) that found a $28 \%$ increase for 
doubled $\mathrm{CO}_{2}$ in a coupled model using CLM4 as its land model component.

In our climate change experiments, we have not considered land use and land cover change. The radiative effect of $\mathrm{N}_{2} \mathrm{O}$ emissions associated with $\mathrm{N}$ deposition is also not included in this study. There are indications that the $\mathrm{C}$ sink benefit offered $\mathrm{N}$ deposition could be significantly offset by the warming potential of associated $\mathrm{N}_{2} \mathrm{O}$ emissions (Dolman et al., 2010; Reay et al., 2008; Xu et al., 2012). Recent studies (Tian et al., 2012) do indicate that the warming effect associated with $\mathrm{N}_{2} \mathrm{O}$ emissions in "overfertilized" regions has completely counteracted the carbon sink effect in some regions of the world. Our model has neither the representation for ozone (produced by elevated $\mathrm{NO}_{x}$ damage to plants; Krupa et al., 2001) nor the NPP and ecosystem carbon decline due to soil acidification from sustained nitrogen deposition (Rasmussen, 1998).

Since the main focus of the paper is on global scale, we have not studied the PFT wise carbon sequestration in detail here. We have also not performed a regional analysis of carbon uptake due to $\mathrm{N}$ deposition. Further, we have quantified the main individual effects and interactions of $\mathrm{N}$ deposition effects with climate warming and $\mathrm{CO}_{2}$ fertilization (Table S3) without the use of factorial analysis of variance (ANOVA) in the present study. A comprehensive investigation of all possible interactions among $\mathrm{N}$ deposition effect, climate warming and $\mathrm{CO}_{2}$ fertilization using ANOVA is beyond the scope of this paper. We intend to use ANOVA for making a detailed quantification of interactions among multiple factors, including land cover change, in our future investigations.

Our study is an idealized modeling study which investigates the near-equilibrium changes and does not quantify the changes from transient forcing. Therefore, it is likely that the magnitudes of the sensitivity parameters estimated in this study are larger than would be obtained in transient simulations (Bala et al., 2012). This study is based on a single model CLM4 which is one of a few models with representations for both carbon and nitrogen cycles. Our understanding of nitrogen cycle and carbon-nitrogen interaction is weak and has major uncertainties (Dolman et al., 2010; Reay et al., 2008; Zaehle and Dalmonech, 2011) and hence more observational and modeling studies, especially multi-model intercomparisons, will be required to provide more confidence.

Increased atmospheric $\mathrm{CO}_{2}$ and increased $\mathrm{N}$ deposition both increase carbon storage in terrestrial ecosystems. In contrast, increased temperatures decrease terrestrial carbon storage. Our model results suggest that throughout simulated past and future decades, human-induced changes in $\mathrm{N}$ deposition are of the same magnitude but opposite in sign to effects of human-induced temperature changes on terrestrial carbon storage. Thus, the increase in terrestrial carbon stock is likely to be the same magnitude as the effect of $\mathrm{CO}_{2}$ fertilization on this stock. However, our results indicate that the effectiveness of $\mathrm{N}$ deposition in increasing terrestrial carbon storage is likely to decrease as time goes on, and thus temperature effects are likely to ultimately overwhelm effects of increased $\mathrm{N}$ deposition. Nevertheless, effects of increased atmospheric $\mathrm{CO}_{2}$ concentrations are likely to dominate the overall response, leading to increased total ecosystem carbon storage.

\section{Supplementary material related to this article is available online at http://www.biogeosciences.net/10/ 7147/2013/bg-10-7147-2013-supplement.pdf.}

Acknowledgements. We thank the funding from the Department of Science and Technology under the grant DST0948. D. Narayanappa is supported by the Divecha Center for Climate Change. R. K. Chaturvedi is supported by the Ministry of Environment and Forests through National Environmental Sciences Fellowship.

Edited by: G. Wohlfahrt

\section{References}

Allen, M. R. and Ingram, W. J.: Constraints on future changes in climate and the hydrologic cycle, Nature, 419, 224-232, 2002.

Bala, G., Kirshna, S., Devaraju, N., Cao, L., Caldeira, K., and Nemani, R.: An estimate of equilibrium sensitivity of global terrestrial carbon cycle using NCAR CCSM4, Clim. Dynam., 40, 1671-1686, doi:10.1007/s00382-012-1495-9, 2012.

Boer, G. J. and Arora, V.: Temperature and concentration feedbacks in the carbon cycle, Geophys. Res. Lett., 36, L02704, doi:10.1029/2008GL036220, 2009.

Bonan, G. B. and Levis, S.: Quantifying carbon-nitrogen feedbacks in the Community Land Model (CLM4), Geophys. Res. Lett., 37, L07401, doi:10.1029/2010GL042430, 2010.

Canadell, J. G., Le Quere, C., Raupach, M. R., Field, C. B., Buitenhuis, E. T., Ciais, P., Conway, T. J., Gillett, N. P., Houghton, R. A., and Marland, G.: Contributions to accelerating atmospheric $\mathrm{CO}_{2}$ growth from economic activity, carbon intensity, and efficiency of natural sinks, P. Natl. Acad. Sci. USA, 104, 1886618870, 2007.

Churkina, G., Brovkin, V., von Bloh, W., Trusilova, K., Jung, M., and Dentener, F.: Synergy of rising nitrogen depositions and atmospheric $\mathrm{CO}_{2}$ on land carbon uptake moderately offsets global warming, Global Biogeochem. Cy., 23, L07401,doi:10.1029/2010GL042430, 2009.

Cox, P. M., Betts, R. A., Jones, C. D., Spall, S. A., and Totterdell, I. J.: Acceleration of global warming due to carbon-cycle feedbacks in a coupled climate model, Nature, 408, 184-187, 2000.

Cramer, W., Bondeau, A., Woodward, I., Prentice, I. C., Betts, R. A., Brovkin, V., Cox, P. M., Fisher, V., Foley, J. A., Friend, A. D., Kucharik, C., Lomas, M. R., Ramankutty, N., Sitch, S., Smith, B., White, A., and Young-Molling, C.: Global response of terrestrial ecosystem structure and function to $\mathrm{CO}_{2}$ and climate change: results from six dynamic global vegetation models, Glob. Change Biol., 7, 357-373, 2001. 
de Vries, W.: Assessment of the relative importance of nitrogen deposition and climate change on the sequestration of carbon by forests in Europe: an overview Introduction, Forest Ecol. Manag., 258, 1-302, 2009.

de Vries, W., Solberg, S., Dobbertin, M., Sterba, H., Laubhahn, D., Reinds, G. J., Nabuurs, G. J., Gundersen, P., and Sutton, M. A.: Ecologically implausible carbon response?, Nature, 451, E1-E3, 2008.

de Vries, W. , Solberg, S., Dobbertin, M., Sterba, H., Laubhann, D., van Oijen, M., Evans, C., Gundersen, P., Kros, J., Wamelink, G. W. W., Reinds, G. J., and Sutton M. A.: The impact of nitrogen deposition on carbon sequestration by European forests and heathlands, Forest Ecol. Manag., 258, 1814-1823, 2009.

Dolman, A. J., van der Werf, G. R., van der Molen, M. K., Ganssen, G., Erisman, J. W., and Strengers, B.: A Carbon Cycle Science Update Since IPCC AR-4, Ambio, 39, 402-412, 2010.

Friedlingstein, P., Dufresne, J. L., Cox, P. M., and Rayner, P.: How positive is the feedback between climate change and the carbon cycle? Tellus B, 55, 692-700, 2003.

Friedlingstein, P., Bopp, L., Ciais, P., Dufresne, J. L., Fairhead, L., LeTreut, H., Monfray, P., and Orr, J.: Positive feedback between future climate change and the carbon cycle, Geophys. Res. Lett., 28, 1543-1546, 2001.

Friedlingstein, P., Houghton, R. A., Marland, G., Hackler, J., Boden, T. A., Conway, T. J., Canadell, J. G., Raupach, M. R., Ciais, P., and Le Quere, C.: Update on $\mathrm{CO}_{2}$ emissions, Nat. Geosci., 3, 811-812, 2010.

Friedlingstein, P., Cox, P., Betts, R., Bopp, L., von Bloh, W., Brovkin, V., Cadule, P., Doney, S., Eby, M., Fung, I., Bala, G., John, J., Jones, C., Joos, F., Kato, T., Kawamiya, M., Knorr, W., Lindsay, K., Matthews, H. D., Raddatz, T., Rayner, P., Reick, C., Roeckner, E., Schnitzler, K.-G., Schnur, R., Strassmann, K., Weaver, A. J., Yoshikawa, C., and Zeng, N.: Climate-carbon cycle feedback analysis: Results from the (CMIP)-M-4 model intercomparison, J. Climate., 19, 3337-3353, 2006.

Galloway, J. N., Dentener, F. J., Capone, D. G., Boyer, E. W., Howarth, R. W., Seitzinger, S. P., Asner, G. P., Cleveland, C., Green, P., Holland, E., Karl, D. M., Michaels, A. F., Porter, J. H., Townsend, A., and Vörösmarty, C.: Nitrogen cycles: past, present, and future, Biogeochemistry, 70, 153-226, 2004.

Govindasamy, B., Thompson, S., Mirin, A., Wickett, M., Caldeira, K., and Delire, C.: Increase of carbon cycle feedback with climate sensitivity: results from a coupled climate and carbon cycle model, Tellus B, 57, 153-163, 2005.

Held, I. M. and Soden, B. J.: Robust responses of the hydrological cycle to global warming, J. Climate., 19, 5686-5699, 2006.

Holland, E. A., Braswell, B. H., Lamarque, J.-F., Townsend, A., Sulzman, J., Müller, J.-F., Dentener, F., Brasseur, G., Levy, II, H., Penner, J. E., and Roelofs, G.-J.: Variations in the predicted spatial distribution of atmospheric nitrogen deposition and their impact on carbon uptake by terrestrial ecosystems, J. Geophys. Res.-Atmos., 102, 15849-15866, 1997.

Horowitz, L. W., Walters, S., Mauzerall, D. L., Emmons, L. K., Rasch, P. J., Granier, C., Tie, X., Lamarque, J.-F., Schultz, M. G., Tyndall, G. S., Orlando, J. J., and Brasseur, G. P.: A global simulation of tropospheric ozone and related tracers: Description and evaluation of MOZART, version 2, J. Geophys. Res.-Atmos., 108, 4784, doi:10.1029/2002JD002853, 2003.
Hungate, B. A., Dukes, J. S., Shaw, M. R., Luo, Y. Q., and Field, C. B.: Nitrogen and climate change, Science, 302, 1512-1513, 2003.

IPCC: Climate Change 2007: The physical science basis, Cambridge University Press, Cambridge, UK and New York, NY, USA, 2007.

Jain, A., Yang, X. J., Kheshgi, H., McGuire, A. D., Post, W., and Kicklighter, D.: Nitrogen attenuation of terrestrial carbon cycle response to global environmental factors, Global Biogeochem. Cy., 23, GB4028, doi:10.1029/2009GB003519, 2009.

Jones, C., Lowe, J., Liddicoat, S., and Betts, R.: Committed terrestrial ecosystem changes due to climate change, Nat. Geosci., 2, 484-487, 2009.

Joos, F., Sarmiento, J. L., and Siegenthaler, U.: Estimates of the Effect of Southern-Ocean Iron Fertilization on Atmospheric Co2 Concentrations, Nature, 349, 772-775, 1991.

Kloster, S., Mahowald, N. M., Randerson, J. T., Thornton, P. E., Hoffman, F. M., Levis, S., Lawrence, P. J., Feddema, J. J., Oleson, K. W., and Lawrence, D. M.: Fire dynamics during the 20th century simulated by the Community Land Model, Biogeosciences, 7, 1877-1902, doi:10.5194/bg-7-1877-2010, 2010.

Korner, C.: Plant $\mathrm{CO}_{2}$ responses: an issue of definition, time and resource supply, New Phytol., 172, 393-411, 2006.

Krupa, S., McGrath, M. T., Andersen, C. P., Booker, F. L., Burkey, K. O., Chappelka, A. H., Chevone, B. I. , Pell, E. J., and Zilinskas, B. A.: Ambient ozone and plant health, Plant Dis., 85, 4-12, 2001.

Lamarque, J.-F., Kiehl, J. T., Brasseur, G. P., Butler, T., CameronSmith, P., Collins, W. D., Collins, W. J., Granier, C., Hauglustaine, D., Hess, P. G., Holland, E. A., Horowitz, L., Lawrence, M. G., McKenna, D., Merilees, P., Prather, M. J., Rasch, P. J., Rotman, D., Shindell, D., and Thornton, P.: Assessing future nitrogen deposition and carbon cycle feedback using a multimodel approach: Analysis of nitrogen deposition, J. Geophys. Res.-Atmos., 110, 1-21, 2005.

Lawrence, D., Oleson, K. W., Flanner, M. G., Thorton, P. E., Swenson, S. C., Lawrence, P. J., Zeng, X., Yang, Z.-L., Levis, S., Skaguchi, K., Bonan, G. B., and Slater, A. G.: Parameterization Improvements and Functional and Structural Advances in Version 4 of the Community Land Model, J. Adv. Mod. Earth Sys., 3, MS000045, doi:10.1029/2011MS000045, 2011.

Le Quéré, C., Raupach, M. R., Canadell, J. G., Marland, G., Bopp, L., Ciais, P., Conway, T. J., Doney, S. C., Feely, R. A., Foster, P., Friedlingstein, P., Gurney, K., Houghton, R. A., House, J. I., Huntingford, C., Levy, P. E., Lomas, M. R., Majkut, J., Metzl, N. , Ometto, J. P., Peters, G. P., Prentice, I. C., Randerson, J. T., Running, S. W., Sarmiento, J. L., Schuster, U., Sitch, S., Takahashi, T., Viovy, N., van der Werf, G. R., and Woodward, F. I.: Trends in the sources and sinks of carbon dioxide, Nat. Geosci., 2, 831-836, 2009.

Lemus, R., Brummer, E. C., Burras, C. L., Moore, K. J., Barker, M. F., and Molstad, N. E.: Effects of nitrogen fertilization on biomass yield and quality in large fields of established switchgrass in southern Iowa, USA, Biomass Bioenerg., 32, 11871194, 2008.

Lloyd, J. and Taylor, J. A.: On the Temperature-Dependence of Soil Respiration, Funct. Ecol., 8, 315-323, 1994.

Magnani, F., Mencuccini, M.,Borghetti, M., Berbigier, P., Berninger, F., Delzon, S., Grelle, A., Hari, P., Jarvis, P. G., Ko- 
lari, P., Kowalski,A. S., Lankreijer, H., Law, B. E., Lindroth, A., Loustau, D., Manca, G., Moncrieff, J. B., Rayment, M., Tedeschi, V., Valentini, R., and Grace, J.: The human footprint in the carbon cycle of temperate and boreal forests, Nature, 447, 848-850, 2007.

Matthews, H. D., Weaver, A. J., and Meissner, K. J.: Terrestrial carbon cycle dynamics under recent and future climate change, J. Climate., 18, 1609-1628, 2005.

Nadelhoffer, K. J., Emmett, B. A., Gundersen, P., Kjonaas, O. J., Koopmans, C. J., Schleppi, P., Tietema, A., and Wright, R. F.: Nitrogen deposition makes a minor contribution to carbon sequestration in temperate forests, Nature, 398, 145-148, 1999.

Newingham, B. A., Vanier, C. H., Charlet, T. N., Ogle, K., Smith, S. D., and Nowak, R. S.: No cumulative effect of 10 years of elevated $\left[\mathrm{CO}_{2}\right]$ on perennial plant biomass components in the Mojave Desert, Glob. Change Biol., 19, 2168-2181, 2013.

Norby, R. J., DeLucia, E. H., Gielen, B., Calfapietra, C., Giardina, C. P., King, J. S., Ledford, J., McCarthy, H. R., Moore, D. J. P., Ceulemans, R., De Angelis, P., Finzi, A. C., Karnosky, D. F., Kubiske, M. E., Lukac, M., Pregitzer, K. S., Scarascia-Mugnozza, G. E., Schlesinger, W. H., and Oren, R.: Forest response to elevated $\mathrm{CO}_{2}$ is conserved across a broad range of productivity, $\mathrm{P}$. Natl. Acad. Sci. USA, 102, 18052-18056, 2005.

Oleson, K. W., Lawrence, D. M., Bonan, G. B., Flanner, M. G., Kluzek, E., Lawrence, P. J., Levis, S., Swenson, S. C., Thornton, P., Dai, A., Decker, M., Dickinson, R., Feddema, J., Heald, C. L., Hoffman, F., Lamarque, J.-F., Mahowald, N., Niu, G.-Y., Qian, T., Randerson, J., Running, S., Sakaguchi, K., Slater, A., Stöckli, R., Wang, A., Yang, Z. L., Zeng, X., and Zeng, X.: Technical Description of version 4.0 of the Community Land Model (CLM) Rep., 266 pp., National Center for Atmospheric Research, Boulder, Colorado, USA, 2010.

Oleson, K. W., Niu, G.-Y., Yang, Z.-L., Lawrence, D. M., Thornton, P. E., Lawrence, P. J., Stockli, R., Dickinson, R. E.,. Bonan, G. B, Levis, S., Dai, A., and Qian, T.: Improvements to the Community Land Model and their impact on the hydrological cycle, J. Geophys. Res.-Biogeo., 113, G01021, doi:10.1029/2007JG000563, 2008.

Pan, Y., Birdsey, R. A., Fang, J., Houghton, R., Kauppi, P. E., Kurz, W. A., Phillips, O. L., Shvidenko, A., Lewis, S. L., Canadell, J. G., Ciais, P., Jackson, R. B., Pacala, S. W., McGuire, A. D., Piao, S., Rautiainen, A., Sitch, S., and Hayes D.: A Large and Persistent Carbon Sink in the World's Forests, Science, 333, 988993, 2011.

Qian, T. T., Dai, A., Trenberth, K. E., and Oleson, K. W.: Simulation of global land surface conditions from 1948 to 2004. Part I: Forcing data and evaluations, J. Hydrometeorol., 7, 953-975, 2006.

Rasmussen, L.: Effects of afforestation and deforestation on the deposition, cycling and leaching of elements, Agr. Ecosyst. Environ., 67, 153-159, 1998.

Reay, D. S., Dentener, F., Smith, P., Grace, J., and Feely, R. A.: Global nitrogen deposition and carbon sinks, Nat. Geosci., 1, 430-437, 2008.

Schimel, D. S.: TERRESTRIAL ECOSYSTEMS AND THE CARBON-CYCLE, Glob. Change Biol., 1, 77-91, 1995.

Schindler, D. W. and Bayley, S. E.: THE BIOSPHERE AS AN INCREASING SINK FOR ATMOSPHERIC CARBON - ES-
TIMATES FROM INCREASED NITROGEN DEPOSITION, Global Biogeochem. Cy., 7, 717-733, 1993.

Stockli, R., Lawrence, D. M., Niu, G. Y., Oleson, K. W., Thornton, P. E., Yang, Z. L., Bonan, G. B., Denning, A. S., and Running, S. W.: Use of FLUXNET in the community land model development, J. Geophys. Res.-Biogeo., 113, G01025, doi:10.1029/2007JG000562, 2008.

Thomas, R. Q., Canham, C. D., Weathers, K. C., and Goodale, C. L.: Increased tree carbon storage in response to nitrogen deposition in the US, Nat. Geosci., 3, 13-17, 2010.

Thompson, S. L., Govindasamy, B., Mirin, A., Caldeira, K., Delire, C., Milovich, J., Wickett, M., and Erickson, D.: Quantifying the effects of $\mathrm{CO} 2$-fertilized vegetation on future global climate and carbon dynamics, Geophys. Res. Lett., 31, L23211, doi:23210.21029/22004GL021239, 2004.

Thornton, P. E. and Rosenbloom, N. A.: Ecosystem model spin-up: Estimating steady state conditions in a coupled terrestrial carbon and nitrogen cycle model, Ecol. Model., 189, 25-48, 2005.

Thornton, P. E. and Zimmermann, N. E.: An improved canopy integration scheme for a land surface model with prognostic canopy structure, J. Climate, 20, 3902-3923, 2007.

Thornton, P. E., Doney, S. C., Lindsay, K., Moore, J. K., Mahowald, N., Randerson, J. T., Fung, I., Lamarque, J.-F., Feddema, J. J., and Lee, Y.-H.: Carbon-nitrogen interactions regulate climate-carbon cycle feedbacks: results from an atmosphereocean general circulation model, Biogeosciences, 6, 2099-2120, doi:10.5194/bg-6-2099-2009, 2009.

Thornton, P. E., Law, B. E., Gholz, H. L., Clark, K. L., Falge, E., Ellsworth, D. S., Goldstein, A. H., Monson, R. K., Hollinger, D., Falk, M., Chen, J., and Sparks, J. P.: Modeling and measuring the effects of disturbance history and climate on carbon and water budgets in evergreen needleleaf forests, Agri. Forest Meteorol., 113, 185-222, 2002.

Tian, H., Lu, C., Melillo, J., Ren, W., Huang, Y., Xu, X., Liu, M., Zhang, C., Chen, G., and Pan S.: Food benefit and climate warming potential of nitrogen fertilizer uses in China, Environ. Res. Lett., 7, 044020, doi::10.1088/1748-9326/7/4/044020, 2012.

Vitousek, P. M. and Howarth, R. W.: NITROGEN LIMITATION ON LAND AND IN THE SEA - HOW CAN IT OCCUR, Biogeochemistry, 13, 87-115, 1991.

Xu, R., Prentice, I. C., Spahni, R., and Niu, H. S.: Modelling terrestrial nitrous oxide emissions and implications for climate feedback, New Phytol., 196, 472-488, 2012.

Yang, X. J., Wittig, V., Jain, A. K., and Post, W.: Integration of nitrogen cycle dynamics into the Integrated Science Assessment Model for the study of terrestrial ecosystem responses to global change, Global Biogeochem. Cy., 23, GB4029, doi:10.1029/2009GB003474, 2009.

Zaehle, S., and Dalmonech, D.: Carbon-nitrogen interactions on land at global scales: current understanding in modelling climate biosphere feedbacks, Current Opinion in Environmental Sustainability, 3, 311-320, 2011.

Zeng, N., Qian, H. F., Munoz, E., and Iacono, R.: How strong is carbon cycle-climate feedback under global warming? Geophys. Res. Lett., 31, L20203, doi:10.1029/2004GL020904, 2004.

Zickfeld, K., Eby, M., Matthews, H. D., Schmittner, A., and Weaver, A. J.: Nonlinearity of Carbon Cycle Feedbacks, J. Climate, 24, 4255-4275, 2011. 